\title{
REVIEW ARTICLE \\ Protein intake in children and growth and risk of overweight or obesity: A systematic review and meta-analysis
}

\author{
Erik Kristoffer Arnesen'**, Birna Thorisdottir², Christel Lamberg-Allardt³ ${ }^{3}$, Linnea \\ Bärebring ${ }^{4}$, Bright Nwaru', Jutta Dierkes 6 , Alfons Ramel ${ }^{7}$ and Agneta Åkesson ${ }^{8}$ \\ 'Department of Nutrition, Institute of Basic Medical Sciences, University of Oslo, Oslo, Norway; ${ }^{2}$ Faculty of Sociology, \\ Anthropology and Folkloristics and Health Science Institute, University of Iceland, Reykjavik, Iceland; ${ }^{3}$ Department \\ of Food and Nutrition, University of Helsinki, Helsinki, Finland; ${ }^{4}$ Department of Internal Medicine and Clinical \\ Nutrition, Institute of Medicine, Sahlgrenska Academy, University of Gothenburg, Gothenburg, Sweden; ${ }^{5}$ Krefting \\ Research Centre, Institute of Medicine, University of Gothenburg, Sweden; ${ }^{6}$ Centre for Nutrition, Department \\ of Clinical Medicine, University of Bergen, Bergen, Norway; ${ }^{7}$ Faculty of Food Science and Nutrition, University of \\ Iceland, Reykjavik, Iceland; ${ }^{8}$ Unit of Cardiovascular and Nutritional Epidemiology, Institute of Environmental Medicine, \\ Karolinska Institutet, Stockholm, Sweden
}

Popular scientific summary

- High-protein diet in infancy is suggested as a risk factor for childhood overweight and obesity.

- A systematic review of randomized controlled trials and prospective cohort studies was performed to assess the evidence of associations between dietary protein and growth, adiposity, and overweight and/or obesity in children.

- There is probable evidence for a cause-and-effect association between higher total and animal protein intake and higher BMI in children up to 18 years of age.

Abstract

Objectives: The aim of this study was to examine the evidence for an association between the dietary protein intake in children and the growth and risk of overweight or obesity up to 18 years of age in settings relevant for the Nordic countries.

Methods: We searched MEDLINE, Embase, Cochrane Central Register of Controlled Trials, and Scopus up to February 26, 2021 for randomized controlled trials (RCTs) or prospective cohort studies assessing for protein intake from foods (total and from different sources) in children. The outcomes include weight, height/length, adiposity indices, and/or risk of overweight and/or obesity. The risk of bias was evaluated with instruments for each respective design (Cochrane's Risk of Bias 2.0 and RoB-NObS). A meta-analysis of five cohort studies was performed. The evidence was classified according to the criteria of the World Cancer Research Fund.

Results: The literature search resulted in 9,132 abstracts, of which 55 papers were identified as potentially relevant. In total, 21 studies from 27 publications were included, of which five were RCTs and 16 were cohort studies. The RCTs found generally null effects of high-protein intake in infants on weight gain, nor that lower protein diets negatively affected growth. All included RCTs had some concern regarding the risk of bias and were limited by small sample sizes. Total protein intake and BMI were assessed in 12 cohorts, of which 11 found positive associations. The meta-analysis revealed a pooled effect estimate of 0.06 $(95 \%$ CI $0.03,0.1) \mathrm{kg} / \mathrm{m}^{2} \mathrm{BMI}$ per one $\mathrm{E} \%$ increment in total protein $\left(I^{2}=15.5\right)$. Therefore, the evidence for a positive relationship between total protein intake and BMI was considered probable. Furthermore, there was probable evidence for an association between higher intake of animal protein and increased BMI. There was limited, suggestive evidence for an effect of total protein intake and higher risk of overweight and/or obesity, while no conclusions could be made on the associations between animal vs. plant protein intake and risk of overweight and/or obesity.

Discussion: In healthy, well-nourished children of Western populations, there is probably a causal relationship between a high-protein intake in early childhood ( $\leq 18$ months $)$ - particularly protein of animal origin - and higher BMI later in childhood, with consistent findings across cohort studies. A lack of RCTs precluded a stronger grading of the evidence. 
Keywords: dietary protein; early life nutrition; infant feeding; growth; BMI; overweight; obesity; metabolic programming; dietary guidelines; systematic review

To access the supplementary material, please visit the article landing page

Received: 26 September 202I; Revised: 20 December 2021; Accepted: 5 January 2022; Published: 2 I February 2022

$\mathrm{T}$ he prevalence rate of overweight and obesity among children has increased dramatically worldwide and constitutes a major global public health problem (1). This rate seems to have plateaued in recent years in the Nordic countries, but is still high $(1,2)$. Primary prevention of overweight and obesity includes the restriction of energy intake by promoting healthier food choices, with focus on fats and sugars, and an increase in energy expenditure with more physical activity. Ensuring an optimal intake of protein in childhood may be another opportunity for primary prevention. This may be especially relevant in the Nordic setting, where protein intake is commonly higher than the recommended intake (3).

Although an adequate amount and quality of dietary protein is crucial for growth, a very high-protein diet in infancy may accelerate growth and increase the likelihood of overweight and obesity in childhood and later in life (4-8). A systematic review of the Nordic Nutrition Recommendations (NNRs) for 2012 revealed that there was convincing evidence for an effect of higher protein intake in infancy and early childhood on increased growth and higher body mass index (BMI) later in childhood (5). In addition, the systematic review found suggestive evidence that intake of animal protein, especially from dairy products, was more strongly associated with growth than that of vegetable protein $(5,9)$.

In updating the NNR for 2022, protein intake in children in relation to growth and obesity was a prioritized subject for a systematic review by the NNR Committee. Criteria for shortlisting topics were published in 2020 (10). Briefly, it was deemed justified to perform a new systematic review if there were important new scientific data since NNR 2012 or substantial health concerns for Nordic or Baltic countries, and no recent, relevant and qualified systematic review was available on the topic (11). A scoping review by the NNR Committee identified new data since 2011 that were considered to have the potential to change the dietary reference values or food-based dietary guidance related to protein intake or animal versus plant-based protein in relation to growth and overweight in children.

The aim of this systematic review was to examine the evidence for an association between total dietary protein intake or protein from different food sources (animal and plant) in children 4 months to 5 years of age, and growth and risk of childhood overweight or obesity.

\section{Methods}

The methodology for the present systematic review followed the guidelines for systematic reviews developed for the NNR $2022(12,13)$ and the Preferred Reporting Items for Systematic reviews and Meta-Analyses $(14,15)$. A protocol was pre-registered online on PROSPERO (https://www.crd.york.ac.uk/prospero) with review ID CRD42021233197. A focused research question was developed by the NNR 2022 Committee, defining the population/participants, intervention/exposure, control, outcome, timeframe, study design and settings (PI/ ECOTSS), in an iterative process with the review authors. The funding source for NNR 2022 was the Nordic Council of Ministers and governmental food and health authorities of Norway, Finland, Sweden, Denmark, and Iceland (10).

\section{Eligibility criteria}

The inclusion and exclusion criteria are outlined in the PI/ECOTSS statement (Table 1). We included original research articles with a prospective cohort design or randomized controlled trials (RCTs) on infants and children between 4 months and 5 years of age at the time of exposure. The exposure comprised reported dietary protein intake (not formula alone), and/or different protein sources, expressed as percentage of energy $(\mathrm{E} \%)$, grams/day, or grams $/ \mathrm{kg}$ body weight (BW). The minimum follow-up or intervention period was 4 weeks for children under 12 months of age and 3 months for ages 1-5 years. The following outcomes measured in children up to 18 years of age were considered: 1) BW ( $\mathrm{kg}$ or z-scores/SDS, i.e. adjusted for age and sex), length/height (cm or z-scores/ SDS), BMI (absolute or z-scores/SDS); 2) body composition indices (e.g. fat mass/fat mass index); or 3) risk of overweight and/or obesity.

We excluded studies assessing formula alone, studies including exclusively pre-term born infants, infants with a very low or high birthweight, infants who were malnourished, had possible growth retardation, or were 
Table 1. Eligibility criteria for population or participants, intervention or exposure, control, outcome, timeframe, study design and settings

\begin{tabular}{|c|c|c|c|c|c|c|}
\hline Population & $\begin{array}{l}\text { Intervention or } \\
\text { exposure }\end{array}$ & Comparators & Outcomes & Timing & Setting & Study design \\
\hline $\begin{array}{l}\text { Children. } \\
\text { Exposure from } \\
4 \text { months to } \\
5 \text { years of age, } \\
\text { outcomes may } \\
\text { be later ages. }\end{array}$ & $\begin{array}{l}\text { I) Total protein } \\
\text { intake (\% of } \\
\text { energy, grams or } \\
\text { grams/kg body } \\
\text { weight) } \\
\text { 2)Amount of } \\
\text { different dietary } \\
\text { protein sources of } \\
\text { animals vs. plants } \\
\text { (\% of energy, } \\
\text { grams or grams/kg } \\
\text { body weight). Main } \\
\text { dietary protein } \\
\text { sources (\% of } \\
\text { energy, grams or } \\
\text { grams/kg body } \\
\text { weight). }\end{array}$ & $\begin{array}{l}\text { Highest versus low- } \\
\text { est protein intake, } \\
\text { for example, defined } \\
\text { by quartiles, or risk } \\
\text { difference per gram } \\
\text { protein from one } \\
\text { source relative to } \\
\text { other sources. } \\
\text { Comparison of } \\
\text { various protein } \\
\text { intake in random- } \\
\text { ized controlled } \\
\text { trials (RCTs). }\end{array}$ & $\begin{array}{l}\text { I)Growth or } \\
\text { anthropometric } \\
\text { outcomes; weight } \\
\text { (kg or z-scores/ } \\
\text { standardized } \\
\text { score), length/ } \\
\text { height (cm or } \\
\text { z-scores/SDS), } \\
\text { body mass index/ } \\
\text { isoBMl (absolute } \\
\text { or z-scores). } \\
\text { 2)Risk of overweight } \\
\text { and/or obesity. } \\
\text { 3)Body composi- } \\
\text { tion indices (e.g. } \\
\text { fat-free mass and } \\
\text { fat mass). }\end{array}$ & $\begin{array}{l}\text { Intake in children } \\
<5 \text { years of age, } \\
\text { preferably divided } \\
\text { in age groups (6-12, } \\
\text { I } 2-24,>24 \text { months). }\end{array}$ & $\begin{array}{l}\text { Relevant for Nordic } \\
\text { settings (excludes, } \\
\text { e.g., populations } \\
\text { with a high preva- } \\
\text { lence of childhood } \\
\text { malnutrition) }\end{array}$ & $\begin{array}{l}\text { RCTs, prospective } \\
\text { cohorts (including } \\
\text { nested case control } \\
\text { and case-cohort } \\
\text { studies). } \\
\text { Study duration: } \\
\text { intervention } \\
\geq 4 \text { weeks if }<\text { I years, } \\
\geq 3 \text { months for I-5 } \\
\text { years of age. }\end{array}$ \\
\hline
\end{tabular}

from settings otherwise not relevant for the Nordic/Baltic population.

\section{Information sources and search strategy}

A comprehensive literature search of MEDLINE (Ovid), Embase (Ovid), Cochrane Central Register of Controlled Trials, and Scopus was performed by research librarians at the medical library in the University of Oslo, Oslo, Norway up to February 26, 2021. The search strategy (Table 2 and the online supplement) was developed in collaboration with the authors, led by E.A. and B.T. and was peer-reviewed by research librarians at the Karolinska Institute in Stockholm, Sweden. There were no date or language limitations in the search strategy. Grey literature searches were not performed.

\section{Selection and data collection process}

Two investigators (L.B. and C.L.A.) independently reviewed titles, abstracts, and full-text articles for inclusions according to the PI/ECOTSS statement (Table 1), first in a pilot test for $10 \%$ of the titles and abstracts, using the web tool Rayyan (https://rayyan.qcri.org) in a blind mode. Potentially eligible papers were retrieved and read in full text by the same two reviewers. Disagreements about inclusion were resolved by discussion or by a third reviewer (A. $\AA$.).

Another two authors (B.N. and J.D.) independently extracted data from the included studies into pre-specified Excel forms. The two forms were merged, and mistakes or disagreements solved also involving a third reviewer (E.A.). All results compatible with each outcome domain listed above in each study were extracted. Among the variables extracted were study design, information on recruitment,
Table 2. Documentation of literature search

\begin{tabular}{lc}
\hline Database & $\begin{array}{c}\text { Number of } \\
\text { retrieved references }\end{array}$ \\
\hline MEDLINE (Ovid) & 3,963 \\
Embase (Ovid) & 5,355 \\
Cochrane Central Register of controlled Trials & 1,358 \\
Scopus & 6,805 \\
Number of references before deduplication & $17,48 \mathrm{I}$ \\
Number of references after deduplication & 9,132 \\
\hline
\end{tabular}

dietary intake, interventions and controls, assessment of outcomes, follow-up, drop-out, and confounders.

\section{Study risk of bias assessment}

Two reviewers (E.A. and A.R.) independently assessed the risk of bias in each included paper, using, for randomized trials, Cochrane's Risk of bias 2.0 tool (16), and for prospective cohort studies, the 'Risk of Bias for Nutrition Observational Studies' (RoB-NObS) developed by the US Department of Agriculture (USDA's) Nutrition Evidence Systematic Review (NESR) (partly based on the Risk of Bias in Non-randomized Studies of Interventions [ROBINS-I] instrument [17-19]).

\section{Synthesis methods}

Studies were scrutinized for synthesis eligibility per outcome, according to the PI/ECOTSS statement. The evidence was synthesized qualitatively, in which the characteristics and context of the included studies, their strengths and limitations, heterogeneity (in study characteristics and results), and relevance were reviewed and described. The main results for each outcome are listed 
in evidence tables. We used mean differences or regression coefficients for the anthropometric outcomes, while odds ratio (OR) was used for studies assessing the risk of overweight and/or obesity. In studies reporting repeated outcome assessments over time, the synthesis focused on the last assessment. If a study measured protein intake at multiple time points, we assessed the findings for intake after 4 months of age.

In line with the protocol, meta-analyses were only performed when more than three independent RCTs or five cohort studies with sufficient homogenous data existed. The meta-analysis approach followed recommendations from the Agency for Healthcare Research and Quality (AHRQ) and the Cochrane Handbook (20-22), and was performed with the 'meta' command in Stata v17. Meta-analyses were performed using a random-effects model. Potential heterogeneity between studies was quantified using the $I^{2}$ statistic, which estimates (range $0-100 \%$ ) the proportion of variance in the pooled estimates attributable to differences in estimates between studies included in the meta-analyses. As only a small number of studies (less than 10 studies) were included in the meta-analysis, evidence of publication bias or small-study effects in meta-analyses was not explored to avoid chance findings (23).

\section{Certainty assessment}

The strength of evidence was categorized according to the World Cancer Research Fund's grading: 'convincing', 'probable', 'limited - suggestive', 'limited - no conclusion' and 'substantial effects unlikely' (10). This evaluation considered the quality (risk of bias), quantity, consistency, and precision in the body of evidence.
According to this classification, the body of evidence is judged as convincing, that is, strong enough to support a causal relationship or lack of a relationship (12), when several conditions are met, one of which is evidence from more than one study type. The evidence is considered as probable when it is strong enough to support that there is a probable causal relationship and must also meet several conditions, that is, there is evidence from at least two independent cohort studies, no unexplained heterogeneity between- or within-study types, good-quality studies to confidentially exclude the possible random or systematic errors, and evidence for biological plausibility. The evidence is considered limited - suggestive when there is evidence from at least two independent cohort studies, a consistent direction of effect, and evidence for biological plausibility. If the evidence is so limited that no firm conclusion can be made, it is considered limited - no conclusion. Finally, if evidence is strong enough to support that there is a convincing absence of a causal relationship, it is considered as substantial effects unlikely.

\section{Results}

\section{Study selection search results}

The results from the literature search, screening and the number of papers or studies excluded (including the reasons), as well as the studies retrieved and included in the systematic review are presented, as shown in Figure 1. The potentially eligible studies excluded after full-text assessment are listed in the online supplement.

\section{Study characteristics}

In total, 27 publications from 21 studies were included, as outlined in Table 3, of these five (quasi) were RCTs
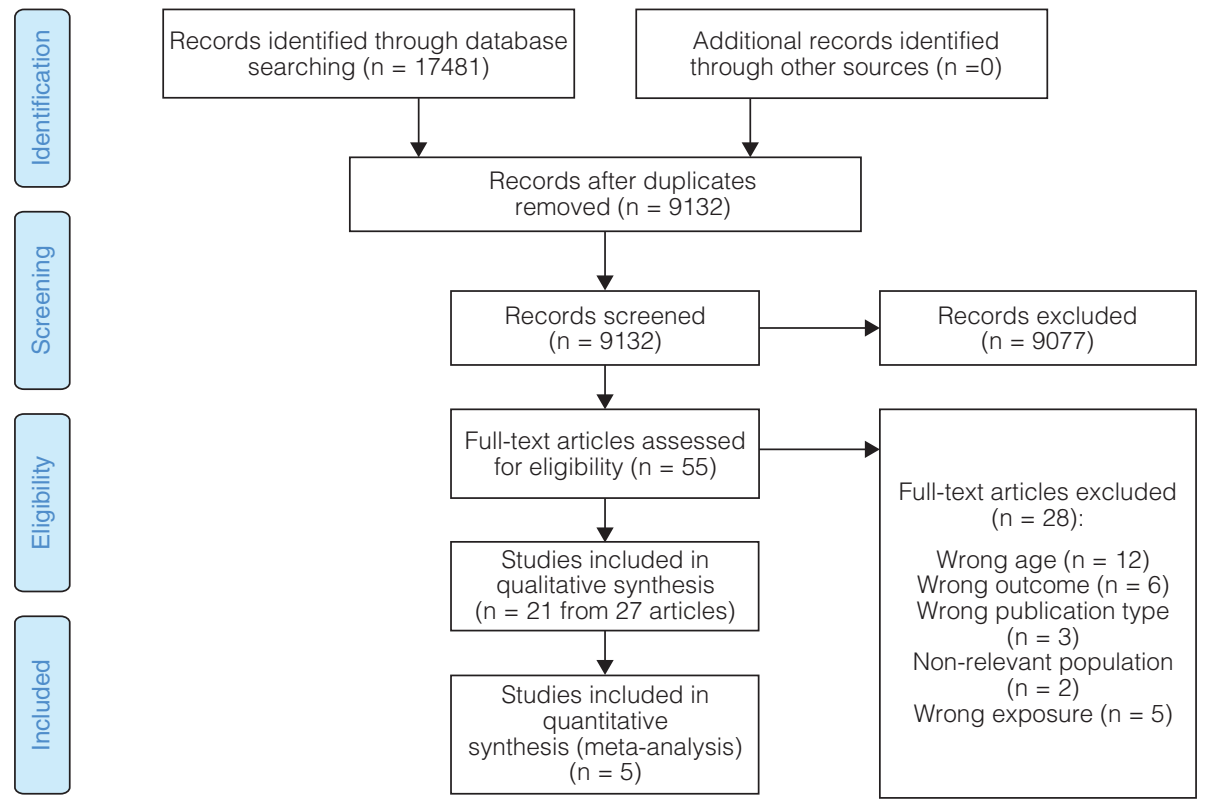

Fig. 1. Study selection flowchart. 


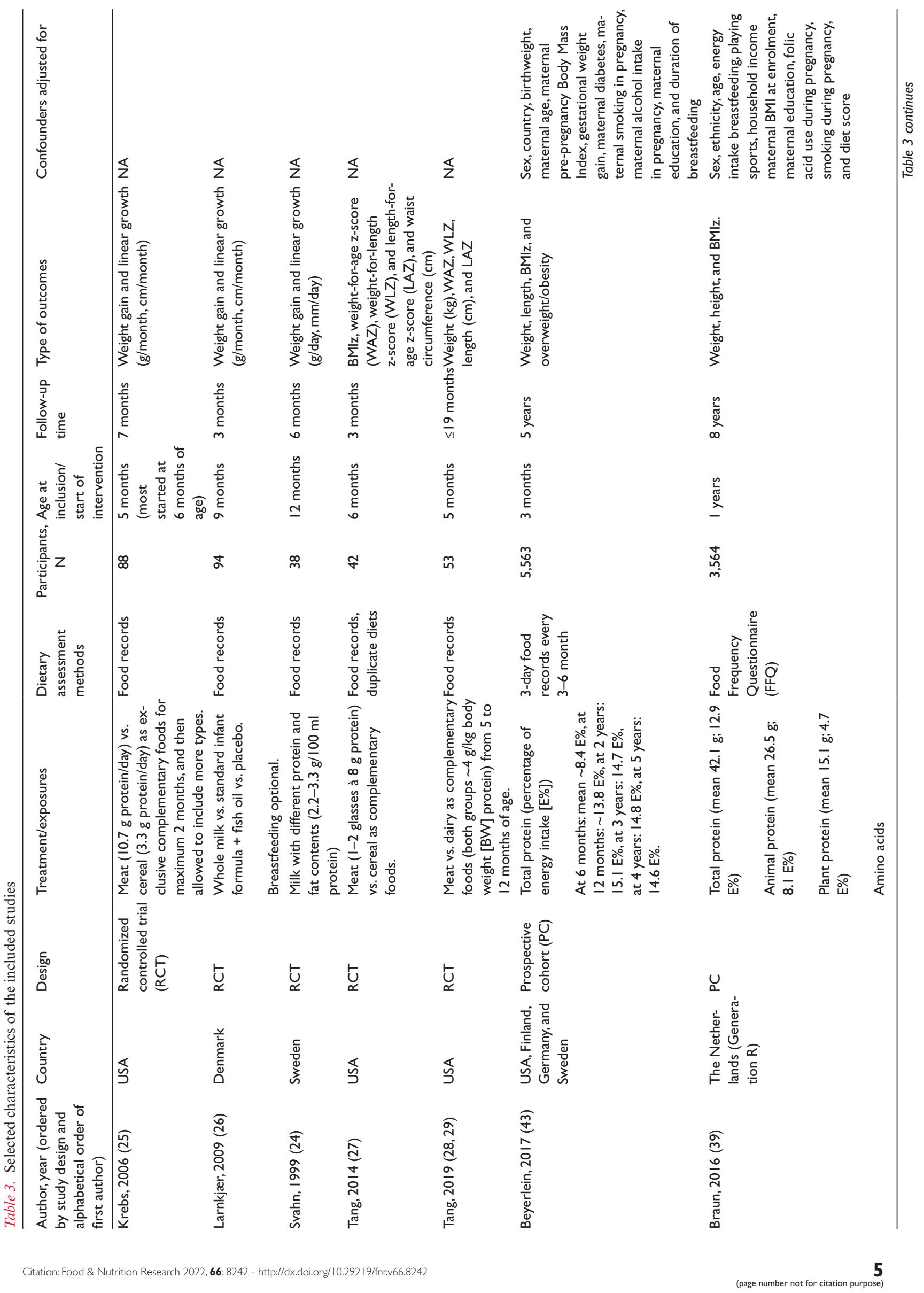




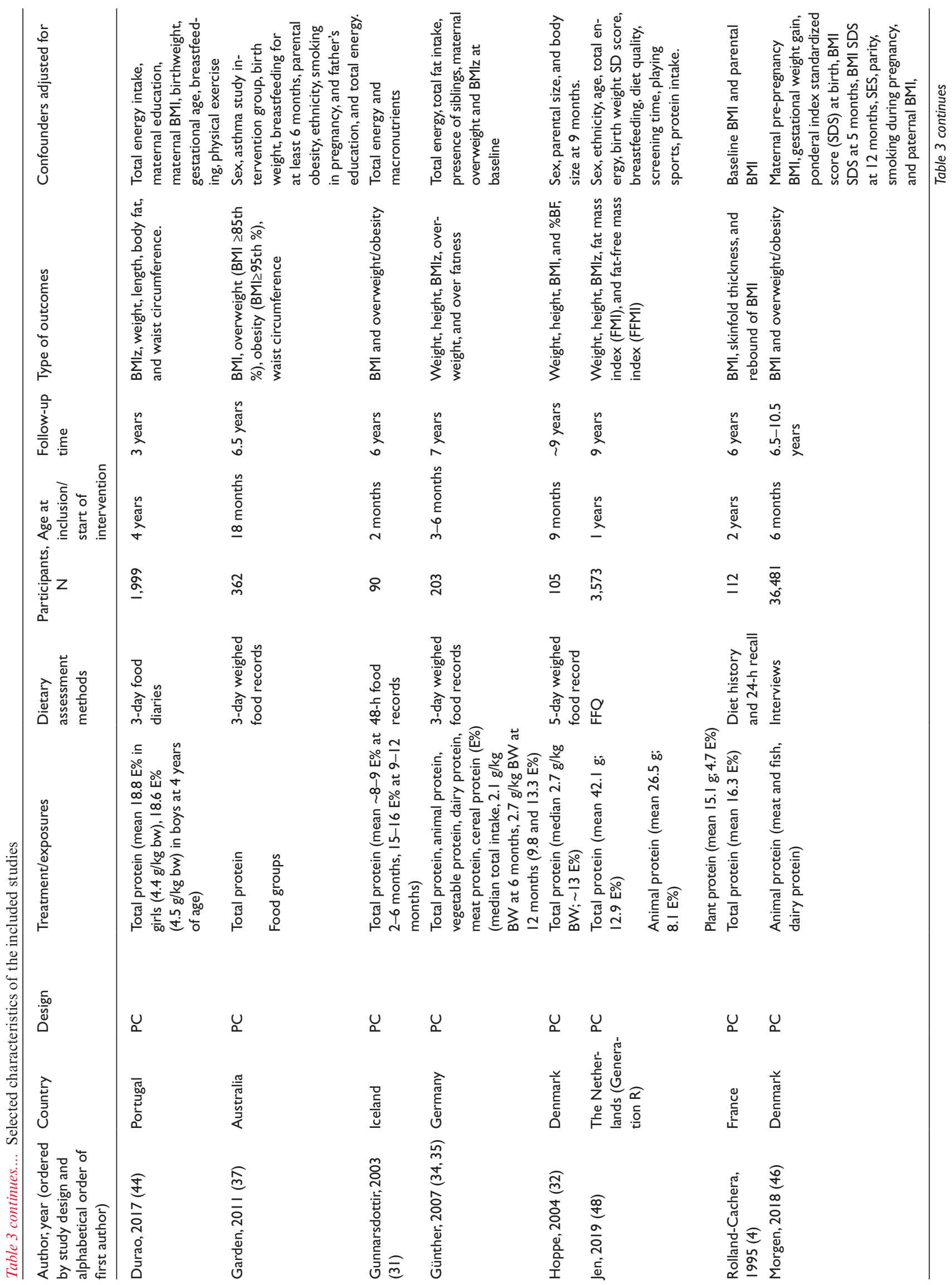




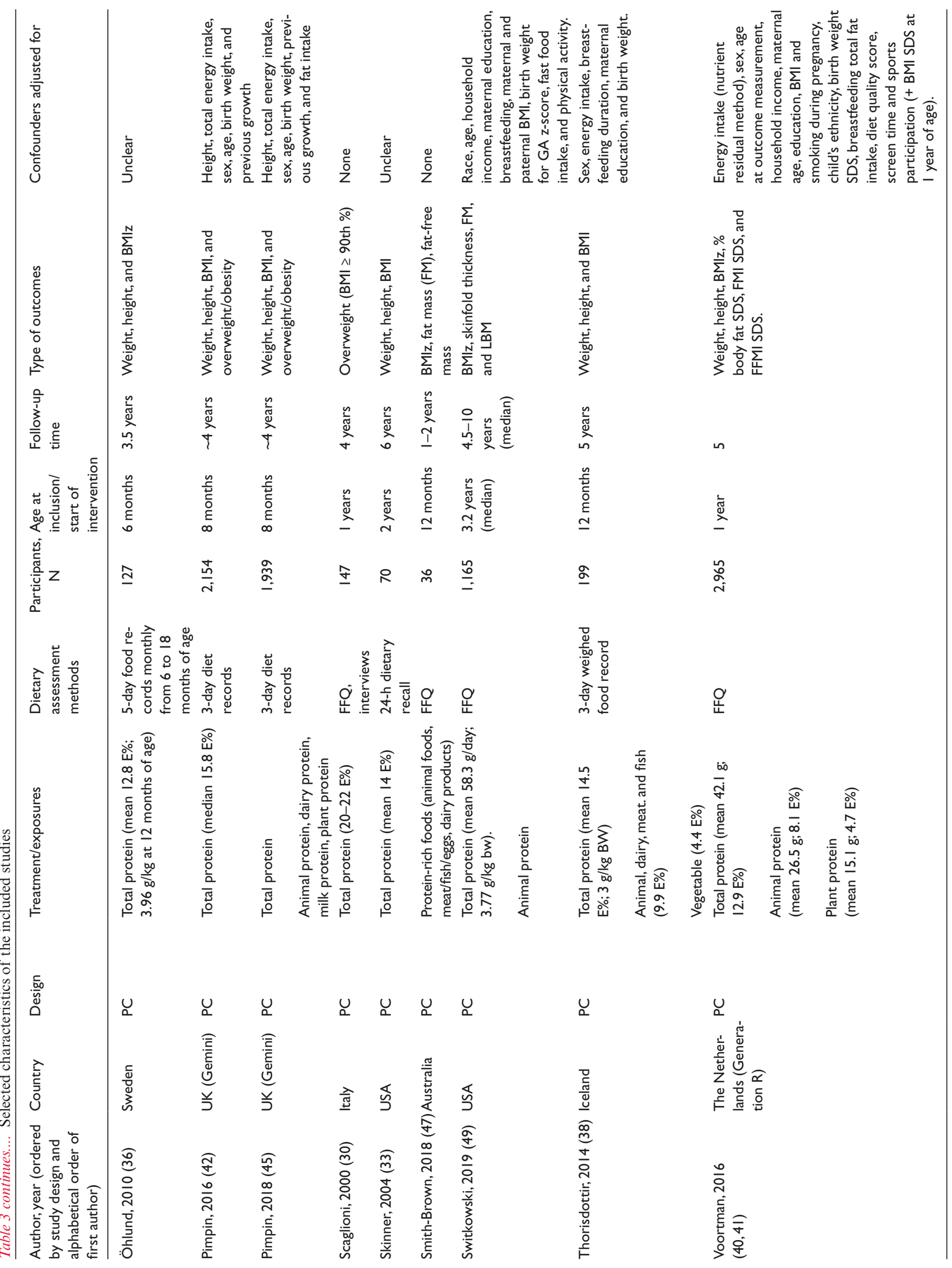


(24-29), including 38-94 children each (total $n=315$ ). All RCTs had a parallel design and were conducted in Sweden (24), Denmark (26), and the United States $(25,27-29)$.

There were 21 publications from 16 cohort studies (4, 30-49) including between 36 (47) and 36,481 (46) (total $n$ $=60,422)$ children for end-point assessments. One of the cohort studies included children from the United States, Finland, Germany, and Sweden (43) while the other study included children from Denmark (32, 46), Iceland (31, 38), Sweden (36), the United Kingdom $(42,45)$, Germany (34), the Netherlands (39-41, 48), France (4), Portugal (44), Italy (30), Australia $(37,47)$, and the United States $(33,49)$. Of all 21 publications from cohort studies, four were from the Dutch Generation R study (39-41, 48), two were from the German Dortmund Nutritional and Anthropometric Longitudinally Designed (DONALD) Study $(34,50)$, and two were from the Gemini study conducted in the UK $(42,45)$.

According to the eligibility criteria, all included studies enrolled mainly healthy, term infants or children (girls and boys), although the Gemini study on twins included a relatively high proportion born preterm (gestational age $<37$ weeks) $(42,45)$. The study with children from four countries included only those with high genetic risk for type 1 diabetes (43). In several studies, infants were recruited at birth, usually at child health's clinics or through advertisements. Age at the start of the intervention or follow-up period ranged from 3 months to 4 years, while the age at the outcome assessment ranged from 6 months to 13 years. Children had been breastfed from birth in all but one RCT, in which only formula-fed infants were included (29). In the cohort studies, inclusion was independent of the breastfeeding status.

\section{Types of intervention or exposure}

Two RCTs used different dairy products or compared cow's milk with formula $(24,26)$, while three RCTs compared different complementary foods consisting of meat, micronutrient-fortified cereal or dairy $(25,27,29)$. In the first two trials, the intake of complementary foods was ad libitum in all study groups. One of the trials included fish oil vs. placebo as a co-intervention; however, this had no effect on the outcome (26). Another trial primarily assessed differences between sources of protein (dairy vs. meat-based complementary foods), so that the absolute protein intake was identical between groups (29).

In all studies, the reported intake of total protein in $\mathrm{g} / \mathrm{kg} \mathrm{BW}$ was more than adequate and within recommended $\mathrm{E} \%$ (3), albeit not quantified in two cohort studies $(46,47)$. In the remaining cohorts, five studies (in seven publications) reported animal protein and plant protein separately $(35,38-40,45,48,49)$; animal protein was further separated into dairy and non-dairy (meat/fish/egg) protein in four of those. Morgen et al. (46) only assessed protein intake from animal sources, while Smith-Brown et al. (47) only assessed servings of animal protein sources as such, not nutrients. Some cohort studies assessed dietary intake at different ages (31, $34,35,43)$.

\section{Outcome assessment}

The duration of the interventions in the RCTs ranged from 3 to 7 months (i.e. final outcomes were assessed at 9-18 months of age), while Tang et al. also carried out outcome assessments 1 year after the intervention at 24 months of age (29). In the cohort studies, the follow-up time between the dietary assessments and outcome ranged from 1 to 2 years to a median 10 years (i.e. from the age of 2-3 years to 13 years at follow-up).

All RCTs reported weight gain and linear growth, expressed in various units, such as $\mathrm{g} / \mathrm{month}$ or $\mathrm{g} / \mathrm{day}$ for weight and $\mathrm{cm} /$ month or $\mathrm{mm} /$ day for length. The RCTs by Tang et al. also reported weight-for-age z-score (WAZ), length-for-age z-score (LAZ), weight-for-length z-score (WLZ) (27, 29), and BMI z-score (BMIz) (29). None of the RCTs reported body composition indices, although one reported change in waist circumference (27). The outcomes were mostly measured by nurses or study personnel in health centers or hospitals.

Eight cohort studies (eight publications) reported associations of protein intake with BMI (31-33, 37, 38, $42,45,51)$, six (10 publications) with BMIz (34-36, 39, $40,43,44,48,49,52$ ), four (five publications) with fat mass index (FMI) or fat mass-index scores (FMIz) (40, 44, 47-49) and three (five publications) with percent body fat $(\% \mathrm{BF})(32,34,35,40,41)$, while four studies (six publications) reported associations between the total protein intake and risk of overweight and/or obesity $(29,34,35,42,43,45)$. Different sources of protein were assessed in four cohort studies in relation to BMIz $(34,39,40,47-49)$, in three cohorts in relation to $\operatorname{BMI}(37,38,45)$ and in two cohorts in relation to overweight and/or obesity $(45,46)$. Body fat indices were measured by DEXA $(32,40,41,48,49)$ or bioimpedance (44), or calculated from skinfold thicknesses (34, 35 ) or total body water (47). Öhlund et al. did assess body fat but not its relation with protein intake (36). Overweight and obesity were classified according to the International Obesity Task Force cutoffs $(34,35,42$, $45,46)$ as BMIz $>1$ or $>2(43)$, and BMI $>75$ th (34) or $\geq 90$ th percentiles (30).

\section{Risk of bias in included studies}

The risk of bias assessment per domain in RCTs is outlined in Fig. 2 and Supplementary Fig. S1. All RCTs had overall some concerns for risk of bias, mostly related to potential awareness of the assigned interventions among 


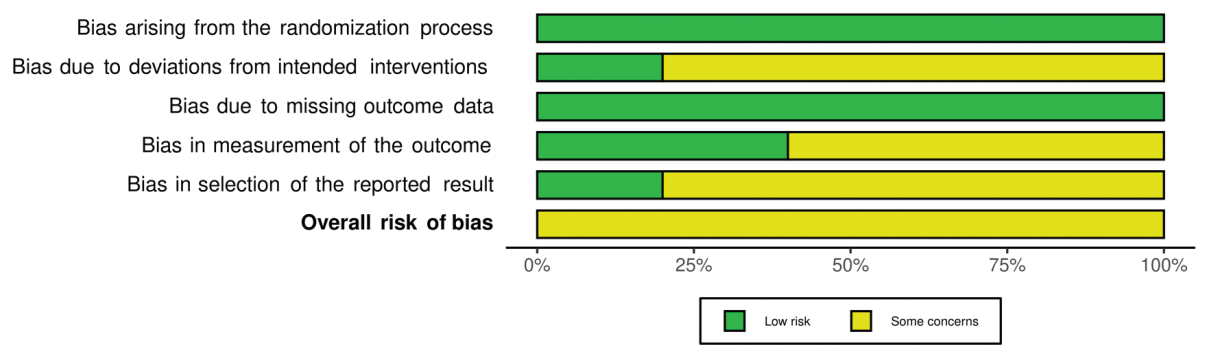

Fig. 2. Summary risk of bias per domain in randomized controlled trials.

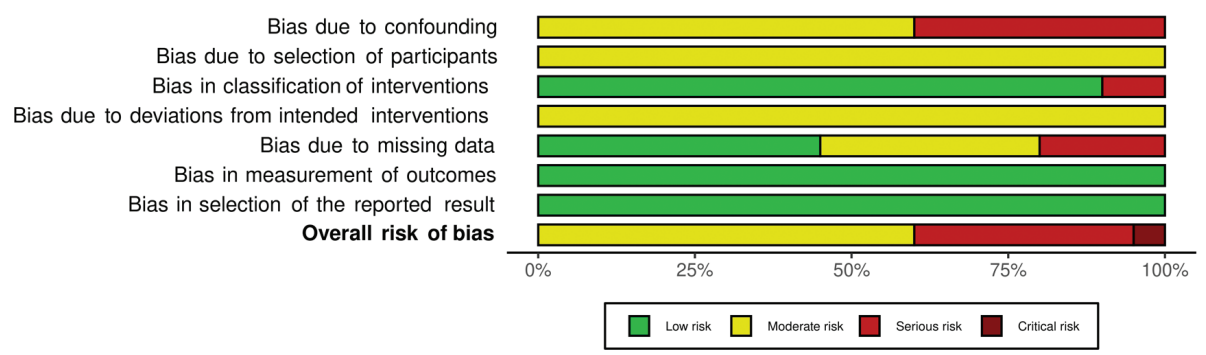

Fig. 3. Summary risk of bias per domain in prospective cohort studies.

the caretakers and outcome assessors, and the lack of reported pre-specified analysis plans (with two exceptions $[26,29])$, increasing the risk of reporting selected results. However, outcomes had objective measurements and would therefore likely not be influenced by detection bias. For the domains of randomization, deviations from the intended interventions, and missing data, all trials were deemed to be low for risk of bias; however, the method of random sequence generation was unclear in all but two $\operatorname{RCTs}(26,28,29)$.

Prospective cohort studies were mostly judged as moderate in overall risk of bias. Due to the potential for confounding inherent in all observational studies, none of the cohort studies reported a low risk of bias for all domains; however, most had a moderate risk of bias in exposure classification, outcome measurement, and the reporting of results (Fig. 3 and Supplementary Fig. S2).

\section{Results per outcome}

Body weight, length/height, and BMI

Randomized controlled trials. Due to heterogeneity in types of intervention and reported outcomes, meta-analysis was not performed with the RCTs; instead, the individual study findings are summarized in Table 4. All RCTs ( $n=5$ ) found generally null effects of either high-protein milk $(24,26)$ or complementary foods $(25,27,29)$ on weight gain, but also indicating that lower protein diets did not negatively affect growth in these infants.

The RCTs assessing meat as complementary foods did not report significant effects on weight, length, or WLZs compared with low-protein cereal $(25,27)$. Tang et al. (29) found an increase in LAZ in the meat group compared with the dairy group from 5 to 12 months. This difference persisted after the end of the intervention (12 months) period up to 24 months of age (mean difference in length 1.9 $\mathrm{cm})$. Weight for age was not significantly different at the 24-month follow-up period.

None of the RCTs reported results of fat mass; however, only Tang et al. (27) reported change in waist circumference.

\section{Prospective cohort studies}

Total protein and weight/BMI. Among the 13 prospective cohort studies assessing the total protein intake and weight and/or BMI/BMIz, eight (10 publications) reported a significant positive or direct association (Table 5) (4, 32, 33, 36-40, 42, 48). The remaining five studies showed positive associations that were limited to one sex or specific age groups; three studies found positive associations in boys, but not in girls (31, 44, 49 ), and one of the studies reported a positive association between protein intake at 4-5 years of age, but not earlier, and BMIz at 5.5 years (43). Finally, one cohort found significant associations with the outcomes at 7 years of age when looking at total protein intake at 1 and 5-6 years of age, but not at 6 months, 1.5-2 or 3-4 years of age, and a significant, positive association with a consistently high intake from 12 to 18-24 months compared with a consistently low intake at these ages $(34,35)$. None of the studies found an inverse association between protein intake and weight and/or BMI/BMIz. 
Table 4. Summary of findings in randomized controlled trials ${ }^{1}$

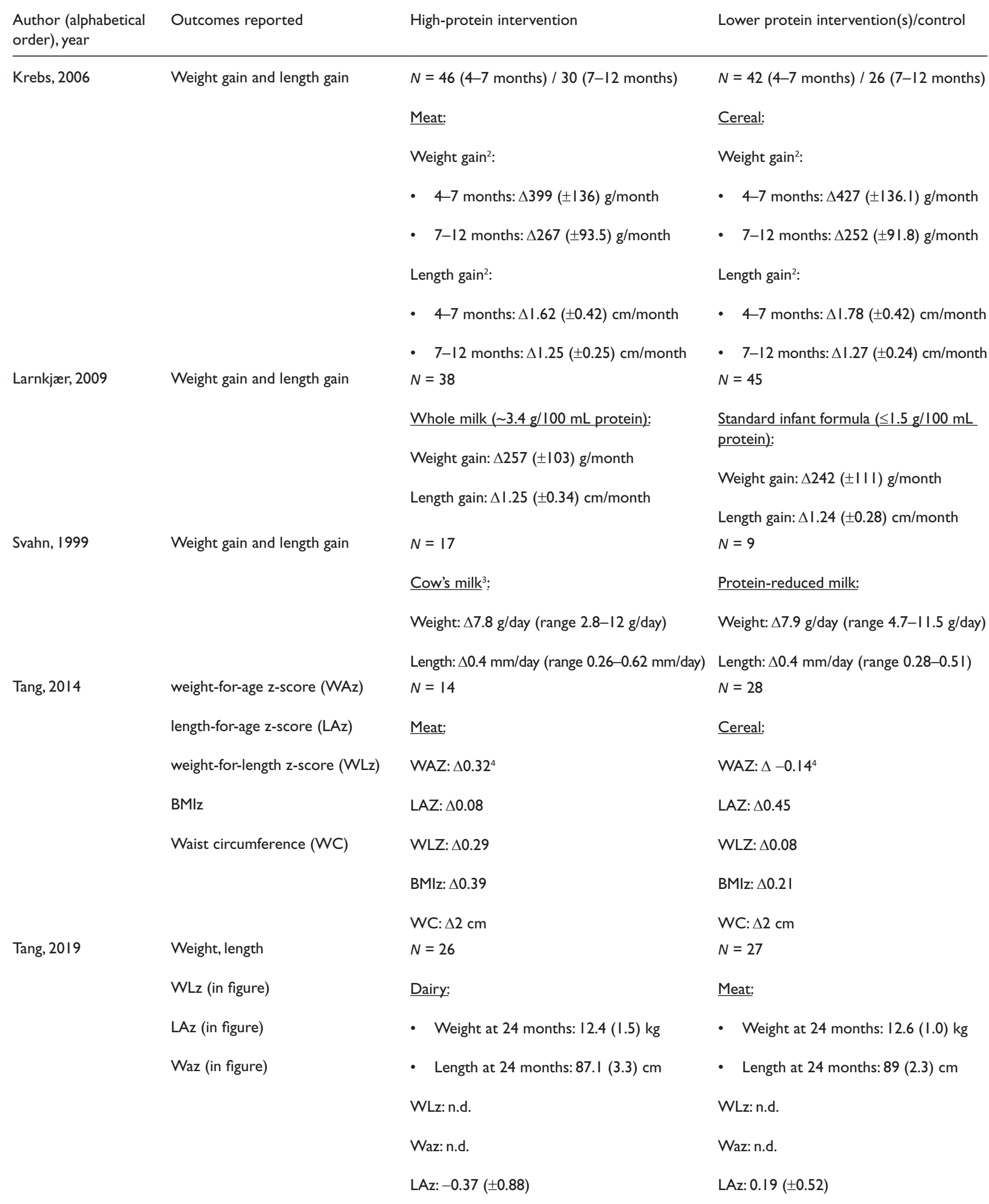

'BMI: Body Mass Index. LAZ: length-for-age z-score. N.d.: no data.WAZ: weight-for-age z-score.WLZ: weight-for-length z-score.WC: waist circumference. ${ }^{2}$ Standard deviations calculated from SE $(\mathrm{SE} \times \sqrt{\mathrm{n}})$.

${ }^{3}$ Cow's milk $=$ mean of low-fat + standard-fat milk groups.

${ }^{4}$ Change calculated as difference in mean at 9 vs. 5 months of age (from the Supplementary data). 
Table 5. Summary of findings from cohort studies - total protein intake ${ }^{1}$

\begin{tabular}{|c|c|c|c|c|c|}
\hline Author, year & $\begin{array}{l}\text { Age at outcome } \\
\text { (y) (ordered } \\
\text { by age) }\end{array}$ & $\begin{array}{l}\text { Outcomes reported } \\
\text { (in final models) }\end{array}$ & Findings (from final models) ${ }^{2}$ & ${ }^{2}$ Effect size & RoB \\
\hline $\begin{array}{l}\text { Öhlund, } \\
2010(36)\end{array}$ & 4 & BMlz & $\uparrow \mathrm{BMIz}$ & $\begin{array}{l}\text { Per g/day protein: } \\
\text { - BMI +0.042 SDS }\end{array}$ & Serious \\
\hline $\begin{array}{l}\text { Pimpin, } \\
2016 \text { (42) }\end{array}$ & 5 & $\begin{array}{l}\text { Weight, height, body } \\
\text { mass index (BMI), and } \\
\text { overweight/obesity }\end{array}$ & $\begin{array}{l}\uparrow \text { Weight, } \uparrow \text { BMI, } \leftrightarrow \text { height, } \\
\leftrightarrow \text { overweight/obesity }\end{array}$ & $\begin{array}{l}\text { At } 5 \text { years of age: } \\
\text { Per I percentage of energy } \\
\text { intake }(\mathrm{E} \%) \text { protein: } \\
\text { - BMI } 0.043 \mathrm{~kg} / \mathrm{m}^{2} \\
\text { - Weight } 0.052 \mathrm{~cm} \\
\text { - Overweight and/or obesity, } \\
\text { OR } 0.93(95 \% \mathrm{Cl} 0.8 \mathrm{I}, \mathrm{I} .07)\end{array}$ & Moderate \\
\hline $\begin{array}{l}\text { Scaglioni, } \\
2000(30)\end{array}$ & 5 & $\begin{array}{l}\text { Overweight } \\
\text { (BMI >90th \%) }\end{array}$ & $\uparrow$ overweight & $\begin{array}{l}\text { Protein intake: } \\
\text { Overweight at } 5 \text { years: } 22 \mathrm{E} \% \text {, } \\
\text { Not overweight at } 5 \text { years: } \\
20 \text { E\%. } \\
\text { Positive association with } \\
\text { overweight ( } P=0.05, \text { OR not } \\
\text { reported) }\end{array}$ & Serious \\
\hline $\begin{array}{l}\text { Beyerlein, } \\
2017(43)\end{array}$ & 5.5 & $\begin{array}{l}\text { Overweight/obesity } \\
(\mathrm{BMl}>\mathrm{I} />2)\end{array}$ & $\begin{array}{l}\text { Intake after } 3.5 \text { and } 4.5 \text { years } \\
\text { of age: } \\
\uparrow \text { Overweight/obesity. } \\
\text { Intake at earlier ages: not } \\
\text { significant (ns) }\end{array}$ & $\begin{array}{l}\text { sPer I E\% protein: } \\
\text { - Overweight: OR = I.03 } \\
\text { (95\% CI I.02, I.05) } \\
\text { - Obesity: OR = I.I2 (I.08, } \\
\text { I.16) }\end{array}$ & Moderate \\
\hline $\begin{array}{l}\text { Voortman, } 2016 \\
(40,4 I) \\
\text { (Generation R) }\end{array}$ & 6 & $\begin{array}{l}\text { Weight, height, } \\
\text { BMlz, \% body fat } \\
\text { standardized score (SDS), } \\
\text { fat mass index (FMI) SDS, } \\
\text { fat-free mass index } \\
\text { (FFMI) SDS. }\end{array}$ & $\begin{array}{l}\uparrow \text { BMI SDS, } \uparrow \text { FMI SDS, } \\
\uparrow \text { body fat percentage (\%BF) } \\
\leftrightarrow \text { FFMI SDS }\end{array}$ & $\begin{array}{l}\text { Per } 10 \mathrm{~g} / \text { day protein: } \\
\text { )- } \text { BMlz +0.05 } \\
- \text { FMI SDS +0.06 } \\
-\quad \% B F+0.06 \text { SDS }\end{array}$ & Moderate \\
\hline $\begin{array}{l}\text { Gunnarsdottir, } \\
2003(3 I)\end{array}$ & 6 & BMI & $\begin{array}{l}\text { Boys: } \uparrow \text { BMI } \\
\text { Girls: ns } \\
\text { All: ns }\end{array}$ & $\begin{array}{l}\text { Per E\% protein: } \\
\text { Boys, intake at } 9 \text { and } 12 \text { months: } \\
\text { - BMI }+0.2 \mathrm{~kg} / \mathrm{m}^{2} \text {. } \\
\text { Boys, intake at } 6 \text { months: ns. } \\
\text { Boys, intake at } 9 \text { and } 12 \text { months: } \\
\text { - Q4 vs. QI: }+2.5 \mathrm{~kg} / \mathrm{m}^{2} . \text { BMI } \\
\text { Girls: ns } \\
\text { All: ns }\end{array}$ & Serious \\
\hline $\begin{array}{l}\text { Thorisdottir, } \\
2014 \text { (38) }\end{array}$ & 6 & Weight, height, and BMI & $\begin{array}{l}\uparrow \mathrm{BMI}, \leftrightarrow \text { weight, } \\
\leftrightarrow \text { height }\end{array}$ & $\begin{array}{l}\text { Per I E\% protein: } \\
\text { - BMI +0.08 kg/m². } \\
\text { Q4 vs. QI: } \\
\text { - BMI +0.8 kg/m². } \\
\text { - Weight }+1.2 \mathrm{~kg}(\mathrm{~ns}) \\
\text { - Height }+0.1 \mathrm{~cm}(\mathrm{~ns})\end{array}$ & Moderate \\
\hline $\begin{array}{l}\text { Durao, } \\
2017(44)\end{array}$ & 7 & $\begin{array}{l}\text { BMlz, body fat, } \\
\text { waist/height }\end{array}$ & $\begin{array}{l}\text { Boys: } \uparrow \mathrm{BMIz,} \uparrow \mathrm{FMI}, \\
\uparrow \text { waist-to-height ratio } \\
\text { ratio } \\
\text { Girls: ns }\end{array}$ & $\begin{array}{l}\text { Per g/day protein: } \\
\text { Boys: } \\
\text { - BMlz +0.205 } \\
\text { Girls: } \\
\text { - BMlz +0.II (ns) }\end{array}$ & Moderate \\
\hline $\begin{array}{l}\text { Günther, } 2007 \\
(34,35)\end{array}$ & 7 & $\begin{array}{l}\text { BMlz, overweight, and } \\
\text { over fatness }\end{array}$ & $\begin{array}{l}\text { Intake at I } 2 \text { months: } \uparrow \text { BMI } \\
\text { SDS, } \uparrow \% \text { BF } \\
\text { Intake at } 6 \text { months, I year, } \\
\text { I.5-2 years and } 3-4 \text { years: ns } \\
\text { High intake at both I } 2 \text { and } \\
\text { I8-24 months: } \uparrow \text { BMI SDS, } \uparrow \\
\% B F \uparrow \text { risk of overweight, } \uparrow \\
\text { risk of over fatness }\end{array}$ & $\begin{array}{l}\text { Per I E\% protein: } \\
\text { Intake at I2 months: } \\
\text { - BMI SDS +0.24 } \\
\text { - In \%BF +0.04 } \\
\text { High intake at I2 and I8-24 } \\
\text { months vs. low intake: } \\
\text { - Risk of overweight OR = } \\
2.39(95 \% \mathrm{Cl} \text { I. I4, 4.99) } \\
\text { - Risk of over fatness OR = } \\
2.28(95 \% \mathrm{Cl} \text { : I.06, 4.88) }\end{array}$ & Moderate \\
\hline
\end{tabular}


Table 5. continues.... Summary of findings from cohort studies - total protein intake

\begin{tabular}{|c|c|c|c|c|c|}
\hline Author, year & $\begin{array}{l}\text { Age at outcome } \\
\text { (y) (ordered } \\
\text { by age) }\end{array}$ & $\begin{array}{l}\text { Outcomes reported } \\
\text { (in final models) }\end{array}$ & Findings (from final models) & ' Effect size & RoB \\
\hline Garden, 20II (37) & 8 & $\begin{array}{l}\text { BMI and waist } \\
\text { circumference }\end{array}$ & $\uparrow \mathrm{BMI}, \leftrightarrow \mathrm{WC}$ & $\begin{array}{l}\text { Per I E\% protein: } \\
-\quad \text { BMI }+0.12 \mathrm{~kg} / \mathrm{m}^{2} \\
- \text { WC }+0.24 \mathrm{~cm}(\mathrm{~ns})\end{array}$ & Moderate \\
\hline $\begin{array}{l}\text { Rolland-Cachera, } \\
\text { I } 995 \text { (4) }\end{array}$ & 8 & $\begin{array}{l}\text { BMI and skinfold } \\
\text { thickness }\end{array}$ & $\begin{array}{l}\uparrow \mathrm{BMI} \uparrow \text { subscapu- } \\
\text { lar skinfold thickness } \\
\text { (total body fat) } \leftrightarrow \text { triceps } \\
\text { skinfold thickness (\%BF) }\end{array}$ & $\begin{array}{l}\text { Correlation coefficients: } \\
\text { - BMI, } r=0.22 \\
\text { - Subscapular skinfold, } r=0.20 \\
\text { - Triceps skinfold, } r=0.1 \text { I (ns) }\end{array}$ & Critical \\
\hline Skinner, 2004 (33) & 8 & BMI & $\uparrow \mathrm{BMI}$ & $\begin{array}{l}\text { Per g/day protein: } \\
-\quad \text { BMI }+0.01 \mathrm{~kg} / \mathrm{m}^{2}\end{array}$ & Serious \\
\hline $\begin{array}{l}\text { Braun, } 2016(39) \\
\text { (Generation R) }\end{array}$ & Up to 9 & $\begin{array}{l}\text { Weight, height, and BMI } \\
\text { SDS }\end{array}$ & $\begin{array}{l}\uparrow \text { Weight SDS, } \uparrow \text { height } \\
\text { SDS, } \uparrow \text { BMI SDS }\end{array}$ & $\begin{array}{l}\text { Per } 10 \text { g/day protein: } \\
\text { - Weight }+0.06 \text { SDS } \\
\text { - Height }+0.03 \text { SDS } \\
\text { - BMI +0.05 SDS }\end{array}$ & Moderate \\
\hline $\begin{array}{l}\text { Jen, } 2019 \text { (48) } \\
\text { (Generation R) }\end{array}$ & Up to 10 & $\begin{array}{l}\text { Weight, height, BMlz, } \\
\text { FMI, and FFMI }\end{array}$ & $\begin{array}{l}\uparrow \text { Weight SDS, } \leftrightarrow \\
\text { Height SDS, } \uparrow \text { BMI SDS, } \\
\uparrow \text { FMI SDS, } \leftrightarrow \text { FFMI }\end{array}$ & $\begin{array}{l}\text { Per } 5 \text { E\% protein: } \\
\text { - Weight }+0.1 \text { I SDS } \\
\text { - Height }+0.05 \text { SDS } \\
\text { - } \text { BMI +0.1I SDS } \\
\text { - FMI +0.09 SDS } \\
\text { - FFMI +0.03 SDS }\end{array}$ & Moderate \\
\hline Hoppe, 2004 (32) & 10 & $\begin{array}{l}\text { Weight, height, BMI, } \\
\text { and \%BF }\end{array}$ & $\begin{array}{l}\uparrow \text { Weight, } \leftrightarrow \text { BMI, } \\
\leftrightarrow \% \mathrm{BF}\end{array}$ & $\begin{array}{l}\text { Per I E\% protein: } \\
\text { - BMI }+0.097 \mathrm{~kg} / \mathrm{m}^{2}(\mathrm{~ns}) \\
\text { - Weight }+0.44 \mathrm{~kg} \\
\text { - Height }+0.5 \mathrm{l} \mathrm{cm} \\
\text { - } \% \text { BF }+0.13(\mathrm{~ns})\end{array}$ & Serious \\
\hline $\begin{array}{l}\text { Switkowski, } \\
2019(49)\end{array}$ & 7.7 and 13 & $\begin{array}{l}\text { BMlz, skinfold thickness, } \\
\text { FMI, lean body mass index }\end{array}$ & $\begin{array}{l}\text { At I3 years of age: Boys: } \\
\uparrow \text { BMlz, } \leftrightarrow \text { skinfolds, } \\
\leftrightarrow \text { lean mass index, } \\
\leftrightarrow \text { FMI } \\
\text { Girls: ns }\end{array}$ & $\begin{array}{l}\text { Per } 10 \mathrm{~g} / \text { day protein } \\
\text { Boys: } \\
\text { - BMI +0.12 SDS }\end{array}$ & Moderate \\
\hline
\end{tabular}

'BMI: Body Mass Index. BW: body weight. E\%: percentage of energy intake. FFM: Fat-free Mass. FFMl: Fat-free Mass Index. FM: Fat Mass. FMI: Fat Mass Index. LBMI: Lean Body Mass Index. ns: not significant. SDS: standardized score.W/ht ratio: waist-to-height ratio. z: z-score. \%BF: body fat percentage.

${ }^{2}$ Arrows indicate the direction of the association.

${ }^{3} \mathrm{FMl}$ and $\mathrm{W} / \mathrm{ht}$ ratio significant with both high-protein intake and high $\mathrm{GL}$.

${ }^{4}$ Estimated from the figure.

The requirement for a meta-analysis was fulfilled by five prospective cohort studies assessing linear associations between $\mathrm{E} \%$ of total protein in relation to $\mathrm{BMI}(n=2,458$ with intake and BMI measurements available) $(31,32,37,38,42)$, with additional data provided by the study authors of one study (31). Subgroup analysis and formal publication bias tests were not feasible due to the few studies. We observed an overall pooled effect estimate of $0.06 \mathrm{BMI} \mathrm{kg} / \mathrm{m}^{2}(95 \%$ CI $0.03,0.10$ ) per one $\mathrm{E} \%$ increment in total protein (Fig. 4) with overall low heterogeneity $\left(I^{2}=15.5\right)$. Among these, Gunnarsdottir et al. found a significant, positive association only in boys, not in girls nor the overall sample (31).

The five included studies in the meta-analysis applied regression models differing in number and types of covariates. Total energy intake was not adjusted for in one study (32). One study did not adjust for sex (31). Three adjusted for birth weight $(37,38,42)$, while two adjusted for breastfeeding $(37,38)$ and for parental weight status $(32$, 37). Other dietary variables were not included in any model. The studies had either moderate $(37,38,42)$ or serious (31, 32 ) overall risk of bias. A few other studies instead reported the total protein intake in $\mathrm{g} /$ day $(1,27)$, or by comparing extreme quartiles or quintiles $(1,25,36,44)$. All these studies reported associations with significantly higher BMI.

Studies that assessed BMIz instead of absolute BMI found increases by $0.04-0.16$ SDS per gram/day of total protein $(36,44), 0.05-0.12$ (in boys) SDS per $10 \mathrm{~g} /$ day protein $(39,40,49), 0.2$ SDS per $1 \mathrm{E} \%$ protein (34), and 0.11 SDS per $5 \mathrm{E} \%$ protein (48).

Animal vs. vegetable protein and weight/BMI

Differential associations with animal and plant protein for BMI/BMIz were reported in eight publications $(35,37-40,45,48,49)$ - two studies assessed sources of 


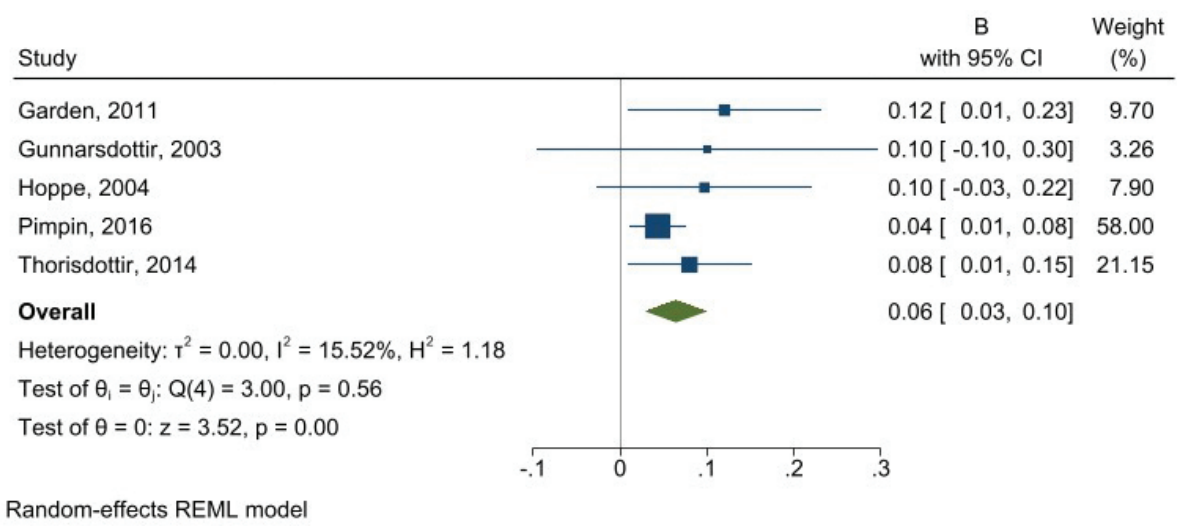

Note: For Gunnarsdottir et al., 95\% confidence intervals were calculated from reported standard errors. REML = restricted maximum likelihood. Fig. 4. Forest plot showing associations between $1 \mathrm{E} \%$ increment in total protein intake and body mass index (BMI).

animal protein alone $(46,47)$. Garden et al. also assessed associations with food groups, including dairy and meats, but not protein intake from these as such (37) (Table 6).

A higher intake of total animal protein, compared with lower, was associated with higher weight and $\mathrm{BMI} /$ BMIz in four out of eight cohorts $(35,38-40,48,49)$, although only in boys in the study by Switkowski et al. (49), while none of the studies found such associations for plant protein. Within different sources of animal protein, dairy protein was significantly associated with increased BMI/BMIz in four studies $(35,39,45,46,48)$; however, Günther et al. (35) only found a significant association for dairy protein intake at 12 months, not 5-6 years of age, and Morgen et al. (46) only found a significant association with BMIz at 7, not 11, years of age. Non-dairy animal protein (e.g. meat protein) was positively associated with BMIz in two of these cohorts $(39,46,48)$. Dairy foods or milk as such (i.e. not specifically dairy protein) was not associated with BMIz in two studies $(37,47)$, while meat was positively associated with BMI in one study (37). The positive associations between animal protein and BMI/ BMIz reflected the associations found with total protein in the same cohorts.

\section{Total protein and body composition}

Associations between total protein intake and body fat percentage $(\% \mathrm{BF})(32,34,40)$, fat mass and/or or fat-free mass $(40,44,48,49)$ were reported in six publications (five cohorts). Four papers also reported waist circumference or waist-height ratios $(37,40,41,44)$.

One of the studies found no significant association between total protein intake and $\% \mathrm{BF}$ (32); one found a positive association between protein intake and $\% \mathrm{BF}$, with a stronger association in girls than boys $(40,41)$, while Günther et al. found a positive association between total protein intake at 12 months, but not earlier, and $\% \mathrm{BF}$ at 7 years of age $(34,35)$. In addition, Rolland-Cachera used skinfold thickness as a proxy for body fat; protein intake was significantly associated with subscapular (indicating total body fat), but not with triceps (indicating \%BF) skinfold thicknesses (4). However, Switkowski et al. found no association with skinfold thickness (subscapular and triceps combined) (49).

There were limited findings regarding fat mass/fat-free mass, that is, positive associations with FMI and null associations with the fat-free mass index in the Generation $\mathrm{R}$ cohort $(40,48)$ but null associations with both fat mass and lean mass in the study by Switkowski et al. (49). In the two studies reporting waist circumference or waist-height ratio, no significant associations with total protein intake were found $(37,44)$.

\section{Animal vs. vegetable protein and body composition}

Only two studies reported on animal protein intake and fat mass or fat-free mass with inconsistent results (40, 48, 49). Jen et al. (48) only found a significant association for total animal and non-dairy animal protein. Günther et al. also found a significant association between total animal protein intake and $\% \mathrm{BF}$, but not for specific animal protein sources (35). Dairy foods or milk was not associated with waist circumference or waist-height ratio, but meats/ fish/eggs was, in two studies $(37,47)$. Smith-Brown et al. also found a positive association between animal protein foods and fat-free mass (47).

Total protein intake and risk of overweight and/or obesity Few studies assessed the relationships between protein intake and odds of overweight and/or obesity, and the findings were mainly in the direction of increased odds. Beyerlein et al. found increased risk of overweight and obesity in 5.5-year-old children with higher protein intake per $1 \mathrm{E} \%$ increment at 3.5 and 4.5 years of age, that is, OR $1.03(95 \%$ CI $1.0,1.05)$ for overweight and OR 1.12 $(1.08,1.16)$ for obesity $(43)$, while Pimpin et al., assessing 
Table 6. Summary of findings from cohort studies - animal or plant protein sources ${ }^{1}$

\begin{tabular}{|c|c|c|c|c|c|}
\hline Author, year & $\begin{array}{l}\text { Age at } \\
\text { outcome } \\
\text { (y) (ordered } \\
\text { by age) }\end{array}$ & Outcomes & Findings $^{2}$ & Effect sizes & RoB \\
\hline $\begin{array}{l}\text { Smith-Brown, } \\
2018 \text { (47) }\end{array}$ & $2-3$ & $\begin{array}{l}\text { BMlz, FM, FFM, } \\
\text { W/ht ratio }\end{array}$ & $\begin{array}{l}\text { Animal protein food: } \leftrightarrow \text { BMlz, } \\
\uparrow \text { FFMlz, } \leftrightarrow, F M I \leftrightarrow \text { F/htz } \\
\text { Dairy: } \leftrightarrow \text { BMlz, } \uparrow \text { FFMlz, } \leftrightarrow, F M I, \\
\leftrightarrow \text { W/htz } \\
\text { Meat, fish, eggs: } \leftrightarrow \text { BMlz, } \uparrow \\
\text { FFMlz, } \leftrightarrow \text { FMI, } \uparrow W / h t z\end{array}$ & $\begin{array}{l}\text { Correlation coefficients: } \\
\text { Animal protein foods: } \\
\text { - BMlz, } r=0.35 \text { (ns) } \\
\text { - FFMlz, } r=0.58 \\
\text { - FMlz, } r=-0.22 \mathrm{I}(\mathrm{ns}) \\
\text { - W/htz, } r=0.37 \text { (ns) } \\
\text { Dairy: } \\
\text { - BMlz, } r=0.29 \text { (ns) } \\
\text { - FFMlz, } r=0.5 \mathrm{I} \\
\text { - FMlz, } r=-0.24 \text { (ns) } \\
\text { - W/htz, } r=0.26 \text { (ns) } \\
\text { Meat, fish, and eggs: } \\
\text { - BMlz, } r=0.39 \text { (ns) } \\
\text { - FFMlz, } r=0.53 \\
\text { - FMlz, } r=-0.084 \text { (ns) } \\
\text { - W/htz, } r=0.55\end{array}$ & Serious \\
\hline $\begin{array}{l}\text { Pimpin, } 2018 \\
(45)\end{array}$ & 5 & $\begin{array}{l}\text { Weight, BMI, } \\
\text { and overweight/ } \\
\text { obesity }\end{array}$ & $\begin{array}{l}\text { Animal protein (non-dairy): } \leftrightarrow \\
\text { weight, } \leftrightarrow \text { BMI, } \leftrightarrow \text { overweight/ } \\
\text { obesity } \\
\text { Dairy protein: } \uparrow \text { weight, } \uparrow \text { BMI, } \\
\leftrightarrow \text { overweight/obesity } \\
\text { Milk protein: } \uparrow \text { weight, } \uparrow \text { BMI, } \\
\uparrow \text { overweight/obesity } \\
\text { Plant protein: } \leftrightarrow \text { weight, } \leftrightarrow \text { BMI, } \\
\leftrightarrow \text { overweight/obesity } \\
\text { Low dairy-high plant protein } \\
\text { diet: }{ }^{-} \text {weight, } \leftrightarrow \text { BMI, } \leftrightarrow \\
\text { overweight/obesity }\end{array}$ & 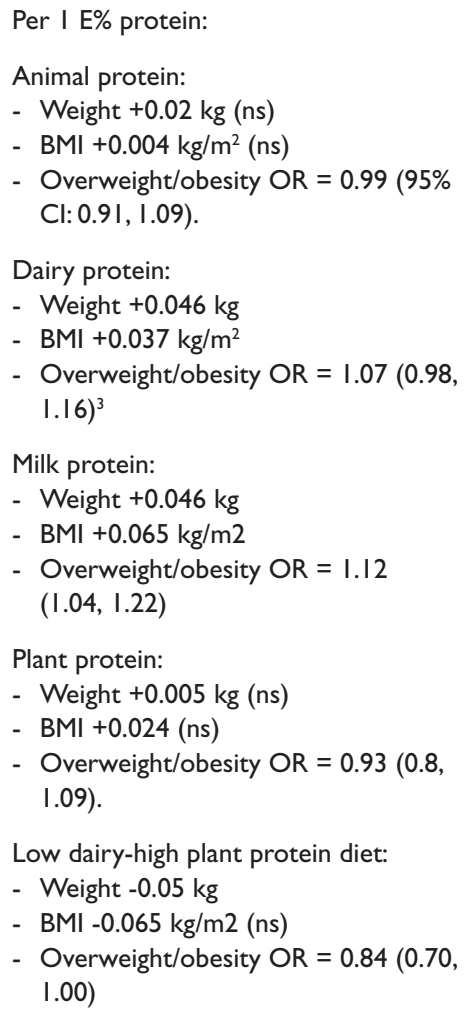 & Moderate \\
\hline $\begin{array}{l}\text { Voortman, } 2016 \\
(40,4 I)\end{array}$ & 6 & $\begin{array}{l}\text { Weight, height, } \\
\text { BMI SDS, FMI } \\
\text { SDS, and FFMI } \\
\text { SDS. }\end{array}$ & $\begin{array}{l}\text { Animal protein: } \uparrow \text { BMI SDS, } \\
\uparrow \text { FMI SDS, } \leftrightarrow \text { FFMI SDS } \\
\text { Vegetable protein: NS }\end{array}$ & $\begin{array}{l}\text { Per I0 g/day protein: } \\
\text { - Animal protein: } \\
\text { - BMI +0.06 SDS } \\
\text { - FMI +0.05 SDS } \\
\text { - FFMI +0.02 SDS (ns) } \\
\text { Vegetable protein: } \\
\text { - BMI +0.0I SDS (ns) } \\
\text { - FMI -0.0I SDS (ns) } \\
\text { - FFMI } 0.00 \text { (ns) }\end{array}$ & Moderate \\
\hline
\end{tabular}


Table 6. continues.... Summary of findings from cohort studies - animal or plant protein sources ${ }^{1}$

\begin{tabular}{|c|c|c|c|c|c|c|}
\hline \multicolumn{2}{|c|}{ Author, year } & $\begin{array}{l}\text { Age at } \\
\text { outcome } \\
\text { (y) (ordered } \\
\text { by age) }\end{array}$ & Outcomes & Findings $^{2}$ & Effect sizes & RoB \\
\hline \multicolumn{2}{|c|}{$\begin{array}{l}\text { Thorisdottir, } \\
2014 \text { (38) }\end{array}$} & 6 & $\begin{array}{l}\text { Weight, height, } \\
\text { and BMI }\end{array}$ & $\begin{array}{l}\text { Animal protein: } \uparrow \mathrm{BMI}, \uparrow \text { weight, } \\
\leftrightarrow \text { height (dairy or meat/fish } \\
\text { protein: ns) } \\
\text { Vegetable protein: } \leftrightarrow \text { BMI, } \leftrightarrow \\
\text { weight, } \leftrightarrow \text { height }\end{array}$ & $\begin{array}{l}\text { Per E\% protein: } \\
\text { - Animal protein: BMI } 0.07 \mathrm{~kg} / \mathrm{m}^{2} \text {. } \\
\text { - Vegetable protein: BMI }-0.08 \mathrm{~kg} / \mathrm{m}^{2} \text { (ns) } \\
\text { Q4 vs. QI: } \\
\text { - Animal protein: weight }+1.5 \mathrm{~kg} \text {, height } \\
\quad+0.9 \mathrm{~cm} \text { (ns). } \\
\text { - Vegetable protein: weight }-0.8 \mathrm{~kg}(\mathrm{~ns}) \\
\text { height }+0.2 \mathrm{~cm} \text { (ns) }\end{array}$ & Moderate \\
\hline $\begin{array}{l}\text { Günther, } \\
\text { (35) }\end{array}$ & 2007 & 7 & $\begin{array}{l}\text { BMlz and body } \\
\text { fat }\end{array}$ & $\begin{array}{l}\text { Intake at } 12 \text { months: } \\
\text { Animal protein: } \uparrow \text { BMI SDS, \%BF } \\
\text { Vegetable protein: } \leftrightarrow \text { BMI SDS, } \\
\leftrightarrow \text { \%BF } \\
\text { Dairy protein: } \uparrow \text { BMI SDS, } \leftrightarrow \\
\text { \%BF } \\
\text { Meat protein: } \leftrightarrow \text { BMI SDS, } \leftrightarrow \\
\text { \%BF } \\
\text { Cereal protein: } \leftrightarrow \text { BMI SDS, } \\
\leftrightarrow \text { \%BF } \\
\text { Intake at } 5-6 \text { years: } \\
\text { Animal protein: } \uparrow \text { BMI SDS, } \uparrow \\
\% \text { BF } \\
\text { Vegetable protein: } \leftrightarrow \text { BMI SDS, } \\
-\% \text { BF } \\
\text { Dairy protein: } \leftrightarrow \text { BMI SDS, } \leftrightarrow \\
\% B F \\
\text { Meat protein: } \leftrightarrow \text { BMI SDS, } \leftrightarrow \\
\% B F \\
\text { Cereal protein: } \leftrightarrow \text { BMI SDS, } \\
\leftrightarrow \% B F\end{array}$ & 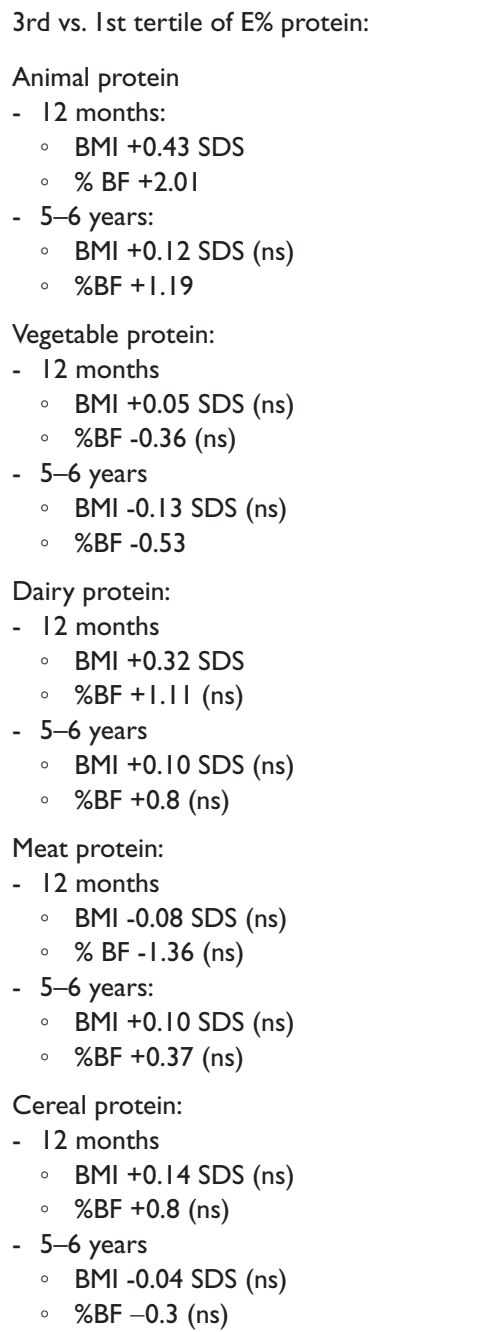 & Moderate \\
\hline $\begin{array}{l}\text { Garden, } \\
\text { (37) }\end{array}$ & 2011 & 8 & BMI and waist & $\begin{array}{l}\text { Dairy foods: } \leftrightarrow \text { BMI, } \leftrightarrow \text { WC } \\
\text { Milk: } \leftrightarrow \text { BMI, } \leftrightarrow \text { WC } \\
\text { Meats: BMI, WC }\end{array}$ & $\begin{array}{l}\text { Per quintile of } \mathrm{g} / \text { day protein: } \\
\text { Dairy foods: } \\
\text { - BMI }-0.2 \mathrm{~kg} / \mathrm{m}^{2}(\mathrm{~ns}) \\
\text { - WC }-0.5 \mathrm{~lm}(\mathrm{~ns}) \\
\text { Milk: } \\
\text { - BMI }-0.11 \mathrm{~kg} / \mathrm{m}^{2} \text { (ns) } \\
\text { - WC }-0.30 \mathrm{~cm} \text { (ns) } \\
\text { Meats: } \\
\text { - BMI }+0.25 \mathrm{~kg} / \mathrm{m}^{2} \\
\text { - WC }+0.59 \mathrm{~cm}\end{array}$ & Moderate \\
\hline
\end{tabular}


Table 6. continues.... Summary of findings from cohort studies - animal or plant protein sources ${ }^{1}$

\begin{tabular}{|c|c|c|c|c|c|}
\hline Author, year & $\begin{array}{l}\text { Age at } \\
\text { outcome } \\
\text { (y) (ordered } \\
\text { by age) }\end{array}$ & Outcomes & Findings $^{2}$ & Effect sizes & RoB \\
\hline Braun, 2016 (39) & Up to 9 & $\begin{array}{l}\text { Weight, height, } \\
\text { and BMI SDS }\end{array}$ & $\begin{array}{l}\text { Animal: weight SDS, height } \\
\text { SDS, BMI SDS } \\
\text { Dairy and non-dairy protein: } \\
\text { Weight SDS, BMI SDS, } \leftrightarrow \\
\text { Height SDS } \\
\text { Vegetable: ns }\end{array}$ & $\begin{array}{l}\text { Per } 10 \text { g/day protein: } \\
\text { Animal protein: } \\
\text { - Weight }+0.07 \text { SDS } \\
\text { - Height }+0.04 \text { SDS } \\
\text { - BMI +0.06 SDS } \\
\text { Vegetable protein: } \\
\text { - Weight }+0.01(n s) \\
\text { - Height }+0.01 \text { (ns) } \\
\text { - BMI }+0.01 \text { (ns) }\end{array}$ & Moderate \\
\hline Jen, 2019 (48) & Up to 10 & $\begin{array}{l}\text { Weight, height, } \\
\text { BMIz, FMI, and } \\
\text { FFMI }\end{array}$ & $\begin{array}{l}\text { Animal protein: weight SDS, } \\
\text { height SDS, BMI SDS, FMI SDS, } \\
\leftrightarrow \text { FFMI SDS } \\
\text { Vegetable protein: NS }\end{array}$ & $\begin{array}{l}\text { Per } 5 \text { E\% protein: } \\
\text { Animal protein: } \\
\text { - Weight +0.I2 SDS } \\
\text { - Height +0.06 SDS } \\
\text { - BMI +0.1I SDS } \\
\text { - FMI +0.09 SDS } \\
\text { - FFMI +0.03 SDS (ns) } \\
\text { Dairy protein: } \\
\text { - Weight +0.13 SDS } \\
\text { - Height +0.07 SDS (ns) } \\
\text { - BMI +0.12 SDS } \\
\text { - FMI +0.06 SDS (ns) } \\
\text { - FFMI +0.0I SDS (ns) } \\
\text { Non-dairy animal protein: } \\
\text { - Weight +0.10 SDS } \\
\text { - Height +0.05 SDS (ns) } \\
\text { - BMI +0.1I SDS } \\
\text { - FMI +0.13 SDS } \\
\text { - FFMI +0.06 SDS (ns) } \\
\text { Vegetable protein: } \\
\text { - Weight +0.05 (ns) } \\
\text { - Height +0.03 (ns) } \\
\text { - BMI +0.04 SDS (ns) } \\
\text { - FMI - } 0.02 \text { SDS (ns) } \\
\text { - FFMI +0.07 SDS (ns) }\end{array}$ & Moderate \\
\hline $\begin{array}{l}\text { Morgen, } \quad 2018 \\
(46)\end{array}$ & 7 and $I I$ & $\begin{array}{l}\text { BMI and } \\
\text { overweight/ } \\
\text { obesity }\end{array}$ & $\begin{array}{l}\text { At II years of age } \mathrm{e}^{4} \\
\text { Dairy protein: } \leftrightarrow \text { BMIz, } \\
\text { overweight } \\
\text { Meat/fish protein: BMlz, } \leftrightarrow \\
\text { overweight }\end{array}$ & $\begin{array}{l}\text { At II years of age: } \\
\text { Dairy (per } 5 \text { g/day): } \\
\text { - BMlz }-0.003 \text { (ns) } \\
\text { - Overweight: OR = } 0.96 \text { (95\% Cl: } 0.89 \text {, } \\
\text { I.04) } \\
\text { Meat and fish (per } 2 \mathrm{~g} / \text { day): } \\
\text { - BMlz +0.0 I3 } \\
\text { - Overweight: OR = } 1.01(0.95,1.07)\end{array}$ & Serious \\
\hline $\begin{array}{l}\text { Switkowski, } 2019 \\
\text { (49) }\end{array}$ & 7.7 and 13 & $\begin{array}{l}\text { BMlz, height, } \\
\text { and LBM }\end{array}$ & $\begin{array}{l}\text { Animal protein: BMlz, } \leftrightarrow \text { height, } \\
\text { LBMI (in boys only), } \leftrightarrow \mathrm{FMI} \\
\text { Plant protein: ns }\end{array}$ & $N R$ & Moderate \\
\hline
\end{tabular}


protein intake at 8 months of age, did not (42). Günther et al. found a consistently high-protein intake from 12 to 18-24 months compared with lower intake associated with increased risk of overweight, defined as $>75$ th percentile of the German reference curves: OR 2.39; $95 \%$ CI $1.14,4.99$ (34), while Scaglioni et al. found a higher baseline intake of protein $(\mathrm{E} \%)$ in children at 1 year of age in those with overweight (BMI $>90$ th percentile) than without overweight at 5 years of age (30).

\section{Animal vs. vegetable protein intake and risk of overweight and/or obesity}

Only two of studies assessing sources of protein reported risk of overweight and/or obesity. In contrast with their null findings for total protein, Pimpin et al. found a higher risk of overweight and/or obesity at 5 years of age with higher intake of fluid milk protein, but not other animal or dairy protein sources or plant protein (45). There was a borderline inverse association (OR $0.84 ; 95 \%$ CI 0.70 , 1.00 ) between the intake of a low dairy/high plant protein dietary pattern and risk of overweight and/or obesity. Morgen et al. (46) only assessed animal protein sources and found no significant associations between dairy or meat/fish protein and overweight at 11 years of age. However, meat and/or fish protein was positively associated with the risk of overweight at 7 years of age.

\section{Certainty in the evidence}

As described above and in Table 4, only one RCT evaluated protein intake on BMI/BMIz (27), finding no effect, but as this study did not directly test the effects of protein intake per se, was small and had a short intervention period, it does not provide strong evidence against the effect of protein. The association between total protein and BMI/BMIz was assessed in 12 independent cohorts, of which 11 found positive associations in the total samples or in subgroups, further corroborated in the meta-analysis of five cohort studies, showing a positive, dose-response increase in $\mathrm{BMI}$ per $\mathrm{E} \%$ higher total protein intake, with little inconsistency regarding the directions. In summary, the evidence of a positive relationship between total protein intake and BMI was considered probable (Table 7). Furthermore, there was probable evidence for an association between higher intake of animal protein and increased BMI, while the evidence was considered probable for no effect of plant protein on BMI.

One of the RCTs found a significant effect of protein intake (source) on weight gain (27), that is, a positive association between protein and weight for age, but not on weight for length or BMI. All RCTs were small, had a short-term intervention, and with varying differences in amounts of protein in the 'high' vs. 'low' groups. Of the cohorts reporting associations between total protein and weight, three of four found a significant, positive association. Due to the limited number of high-quality studies and somewhat inconsistent results, the evidence for a causal effect of total protein and/or animal protein on excessive weight gain was considered limited but suggestive. There was probable evidence for no effect of plant protein on excessive weight gain.

Regarding body composition, no RCT assessed effects on body fat or fat-free mass. Of the six cohorts assessing associations between total protein or animal protein and body fat (including skinfold thicknesses), both positive and no significant associations were found. The evidence for a positive effect of total protein on body fat was considered limited but suggestive, while the evidence for animal protein was limited and inconclusive due to few studies and inconsistent conclusions. However, the results of plant protein intake and body fat were consistent (i.e. no association), albeit with few studies. Evidence for a lack of association was therefore considered limited but suggestive.

There was also limited, suggestive evidence for an effect of total protein intake and higher risk of overweight and/ or obesity, as positive associations were found in three of four cohorts; however, the results were difficult to compare directly due to methodological heterogeneity. Conclusions could not be made on the associations between animal or plant protein intake and the risk of overweight or obesity, that is, the evidence was considered limited and inconclusive.

\section{Discussion}

This systematic review found some support for an association between higher intake of protein and increased BMI or BMI z-scores in healthy, well-nourished children based on prospective cohort studies alone, including a de novo meta-analysis of five prospective studies. There is also some evidence that this association is driven by protein from animal sources, while the intake of protein from plant sources was not associated with later BMI or body fat. Available data on protein intake and subsequent risk of overweight or obesity are limited, and the findings are unclear, possibly due to limited power.

The seemingly discordant results between RCTs and prospective studies in this systematic review, where the RCTs, in contrast with the cohort studies, generally observed null effects, need to be carefully appraised. Although inference with respect to causality is usually in favor of RCTs, several methodological constraints, such as short intervention periods, small sample sizes, and the nature of the interventions and comparisons, clearly affect the possibility to obtain significant findings in these studies. In this context, it is important to note based on few studies that no adverse effects on growth from protein-reduced diets compared with high-protein diets were observed in the RCTs. In the light of the need for the 
Table 7. Summary of outcomes and strength of evidence

\begin{tabular}{|c|c|c|c|c|}
\hline Outcome & Exposure or intervention & $\begin{array}{l}\text { Number of participants' } \\
\text { (number of independent } \\
\text { studies) }\end{array}$ & $\begin{array}{l}\text { Effect (direction and } \\
\text { number of studies) }\end{array}$ & Strength of evidence \\
\hline \multirow[t]{3}{*}{ Body mass index/BMlz } & Total protein & $\begin{array}{l}\text { Cohorts: 9,462 (I2) } \\
\text { Randomized controlled } \\
\text { trials (RCTs): } 42(\mathrm{I})\end{array}$ & $\begin{array}{l}\text { Cohorts: } \uparrow 12 \\
\text { RCTs: } \leftrightarrow\end{array}$ & Probable \\
\hline & Animal protein & $\begin{array}{l}\text { Cohorts: } 29083(8) \\
\text { RCTs: } 42(1)\end{array}$ & $\begin{array}{l}\text { Cohorts: } \uparrow 7^{2} \\
\text { RCTs: } \leftrightarrow\end{array}$ & Probable \\
\hline & Plant protein & $\begin{array}{l}\text { Cohorts: 6,645 (5) } \\
\text { RCTs: } 0\end{array}$ & Cohorts: $\leftrightarrow$ & Probable (no effect) \\
\hline \multirow[t]{3}{*}{ Weight gain/weight for age } & Total protein & $\begin{array}{l}\text { Cohorts: 5,860 (4) } \\
\text { RCTs: } 292(5)\end{array}$ & $\begin{array}{l}\text { Cohorts: } 3 \\
\text { RCTs:^I }\end{array}$ & Limited (suggestive) \\
\hline & Animal protein & $\begin{array}{l}\text { Cohorts: 5,760 (3) } \\
\text { RCTs: } 207 \text { (4) }\end{array}$ & $\begin{array}{l}\text { Cohorts: } \uparrow 3^{3} \\
\text { RCTs: } \uparrow \text { I }\end{array}$ & Limited (suggestive) \\
\hline & Plant protein & $\begin{array}{l}\text { Cohorts: 5,760 (3) } \\
\text { RCTs: } 0\end{array}$ & Cohorts: $\leftrightarrow$ & Probable (no effect) \\
\hline \multirow[t]{3}{*}{ Length gain/length for age } & Total protein & Cohorts: 4,695 (4) & $\begin{array}{l}\text { Cohorts: } \\
\text { RCTs: } \leftrightarrow\end{array}$ & Limited (inconclusive) \\
\hline & Animal protein & Cohorts: 4,673 (3) & 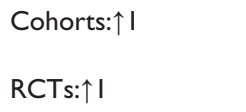 & Limited (inconclusive) \\
\hline & Plant protein & Cohorts: 4,673 (3) & Cohorts: $\leftrightarrow$ & Limited (inconclusive) \\
\hline \multirow[t]{3}{*}{$\begin{array}{l}\text { Body fat percentage/Fat Mass } \\
\text { Index }\end{array}$} & Total protein & Cohorts: 6,368 (6) & Cohorts: $\uparrow 3$ & Limited (suggestive) \\
\hline & Animal protein & Cohorts: 4,303 (4) & Cohorts: $\leftrightarrow 3$ & Limited (inconclusive) \\
\hline & Plant protein & Cohorts: 4,278 (3) & Cohorts: $\leftrightarrow$ & Limited (suggestive) \\
\hline \multirow[t]{3}{*}{ Overweight/obesity } & Total protein & Cohorts: 6,798 (4) & Cohorts: $\uparrow 3$ & Limited (suggestive) \\
\hline & Animal protein & Cohorts: 10,105 (2) & Cohorts: $\uparrow^{4}$ & Limited (inconclusive) \\
\hline & Plant protein & Cohorts: I,534 (I) & Cohorts: $\leftrightarrow$ & Limited (inconclusive) \\
\hline
\end{tabular}

'N participants with the respective outcomes and exposure.

${ }^{2}$ Of which only meat (no dairy) in two studies and only dairy in one study.

${ }^{3}$ Only dairy in one study.

${ }^{4}$ Only milk.

population within the Nordic countries and elsewhere, to move to a more plant-based diet, more probative studies assessing the safety and adequacy of lower protein diets for young children are needed.

\section{Comparison with other reviews}

A systematic review by Hörnell et al., for the NNRs 2012, assessed protein intake in relation to growth and development, in children up to 18 years of age from studies published in 2000-2012 (5). Based on 13 studies, including one RCT (53), the authors concluded the evidence to be convincing that 'higher protein intake in infancy and early childhood is associated with increased growth and higher BMI in childhood', while there was limited-suggestive evidence for a stronger association with growth of animal protein, especially from dairy, compared with vegetable protein. Hörnell et al. included a wider age range and also infant formula trials such as the large European Childhood Obesity Project RCT (53).

More recently, Stokes et al. reviewed the association between protein intake in infants and children up to 2 years of age and childhood obesity-related outcomes in a systematic review including only prospective cohort studies (8). Several studies included in this review were also included by Stokes et al. (30-32, 34, 35, 38-42, 45, 46, 48), and they performed a meta-analysis on total protein intake and BMI with three of the five studies included in our meta-analysis, obtaining similar results. In another recent 
systematic review, Ferré et al. looked at associations between protein intake specifically during the second year of life and weight gain and overweight and/or obesity in childhood (7). They did not include any of the RCTs, but several of the same cohort studies as in the present systematic review, and concluded that there are 'indications' for an effect of protein intake during the second year of life and obesity risk. One of the RCTs included by Ferré et al. found that infants randomized to a protein-reduced milk from 12 months of age had reduced FMI and \%BF at 2 years of age compared with those on standard cow's milk consumption (54). However, the intervention milk was also fortified with micronutrients and synbiotics, and thus could not be included in our systematic review.

Other recent systematic reviews have focused on the effects of protein intake specifically from infant formulas and growth and weight-related outcomes in RCTs (55, 56), thus finding that lower protein formulas seem to lead to adequate growth in the short term. They included studies mostly in infants younger than our eligibility criteria.

Effects of complementary foods and beverages, rather than protein per se, have also been reviewed, including in a 2019 systematic review prepared for the USDA (57). Although the research questions were not directly comparable, they found moderate evidence that the amount of meat as complementary foods did not favorably or unfavorably affect growth or body composition, while there was insufficient evidence for effects on overweight and/or obesity.

\section{Potential mechanisms}

Several hypotheses have been suggested to explain the link between higher intake of protein - driven by animal protein - and increased BMI in healthy, well-nourished children. One of them concerns the effects of amino acids on insulin and insulin-like growth factor 1 (IGF-I), an anabolic factor that promotes growth and adipogenesis (58). Especially branched-chained amino acids (BCAA) are hypothesized to stimulate insulin/IGF-1 secretion, and a higher intake of BCAA has also been associated with overweight in children (59). We did not include potentially mediating variables such as insulin or IGF-1 in this systematic review, and can therefore not allude to the mechanisms behind the observed associations.

We did not systematically assess the evidence for certain critical time periods for 'programming' of adiposity (58); however, the included studies did not show any clear pattern. For instance, the DONALD study found that a high-protein intake at 12 months of age and later, but not at 6 months, was associated with later overweight, suggesting, according to the authors, that protein intake during the period of complementary feeding and the transition to the family's diet was decisive (34). However, positive associations between protein intake and BMI were also reported in studies assessing later exposures. For instance, Günther et al. found an association between protein intake at 5-6 years of age and BMI. However, Beyerlein et al. only found an association of protein intake 4-5 years of age, not earlier (43). Rolland-Cachera also found an association between protein intake at 2 years of age and earlier BMI rebound, which, in turn, is related to higher adiposity $(4,51)$; however, this was not confirmed in a subsequent UK cohort (60). In the DONALD study, a high-protein intake was associated with higher BMI SDS at adiposity rebound in girls, but not in boys, but not with the timing of adiposity rebound (50).

We were also unable to separately assess any sex differences, although some studies reported stronger effects in boys than in girls $(31,49)$. This difference is potentially age dependent (39-41) due to different growth patterns or variations in the sensitivity to growth and sex hormones between sexes. Overall, the effect modification of age or gender on the effect of protein intake on excess weight or adiposity seems unclear and warrants further investigation in future studies.

\section{Public health relevance and implications}

Although the effect size $\left(0.06 \mathrm{~kg} / \mathrm{m}^{2}\right.$ higher BMI per E\% from protein) in the meta-analysis could be regarded as small, such changes in mean BMI still shift the population distribution upwards and increase the chances of overweight and obesity (61). A previous individual-level meta-analysis of predictors of childhood obesity by Druet et al. (62) found that each one unit increase in weight SDS from 0 to 1 year of age was associated with a two-fold higher odds of childhood obesity and 23\% higher odds of adult obesity. Weight gain from 0 to 2 years of age was also strongly and significantly related to a more than twofold higher odds of childhood obesity in a subset. A rapid weight gain in especially the first year of life, adjusted for birth weight, is also associated with later overweight and/ or obesity (63). Obesity in childhood and adolescence (7-18 years) is, in turn, strongly associated with having obesity in adulthood, although most adults with obesity did not have obesity in childhood (64). Evidently, overweight and obesity have negative consequences during childhood as well, including discrimination, stigma, musculoskeletal problems, and increased incidence of asthma. $\mathrm{BMI}$ in childhood and adolescence is also associated with the risk of cardiovascular disease $(65,66)$, type 2 diabetes, and mortality in adults (67).

\section{Strengths and limitations}

In this work, we followed rigorous, state-of-the art methodologies for systematic reviews, with grading of the certainty of the evidence to help translating the findings into dietary guidelines. Limitations include the availability of few high-quality studies with comparable assessments, 
which prevented us from performing meta-analyses for several outcomes as well as from subgroup analyses, dose-response-meta-analysis, and the formal assessment of reporting bias. We were able to meta-analyze the association between $\mathrm{E} \%$ from total protein and $\mathrm{BMI}$ in cohort studies, although the studies were small and had different risks of bias. Due to concomitant growth, defining adiposity in children based on BMI is complicated (68). This being said, BMI is a well-accepted reference for assessing overweight and obesity in large populations (69) and is strongly associated with body fat as measured by DEXA (70). According to Simmonds et al., BMI does have high sensitivity and specificity (and similar to waist circumference) for obesity in children, but less for overweight (71).

Additional limitations include the generally small sample sizes in the RCTs, which compromised statistical power and likely affected the ability to detect significant effects or changes in outcome variables. As to the observational studies, the dietary intake assessments are likely to some extent be affected by reporting errors, and the validity of the assessment methods were, with few exceptions $(39,40,48)$, not reported. Many of the studies included in our analysis did not control protein intake for total energy intake, which is a limitation. Thus, higher protein intake could also be associated with higher total energy intake from other sources, albeit the studies in the meta-analysis were adjusted for energy intake ( $\mathrm{E} \%$ from protein). Moreover, few cohort studies with long follow-up assessed changes in protein intake over time. Theoretical dietary substitution effects, that is, replacing protein with other macronutrients or animal with plant protein, have been examined in a very few studies $(39,40,42,48)$ and were not evaluated separately.

\section{Conclusion}

In this systematic review, we focused on healthy well-nourished children of Western populations below the age of 5 years. Based on consistent findings across cohort studies, it is probable that higher protein intake, in particular of animal origin, in children $\leq 18$ months of age is linked to subsequent higher BMI. Limitations in the evidence were due to low availability of high-quality studies with comparable assessments and a lack of RCTs prevents higher evidence grading.

\section{Acknowledgments}

The authors thank Hilde Strømme at the University of Oslo Library of Medicine and Science for performing the literature search and providing full-text articles, and Gun Brit Knutssön and Sabina Gillsund at Karolinska Institutet University Library for peer reviewing the search strategy.

\section{Conflicts of interest and funding}

The authors declare no potential conflicts of interest. Partial funding was received from the Nordic Council of Ministers and governmental food and health authorities of Norway, Finland, Sweden, Denmark, and Iceland.

\section{Registration}

PROSPERO registration number: CRD42021233197.

\section{References}

1. NCD Risk Factor Collaboration. Worldwide trends in bodymass index, underweight, overweight, and obesity from 1975 to 2016: a pooled analysis of 2,416 population-based measurement studies in 128.9 million children, adolescents, and adults. Lancet 2017; 390(10113): 2627-42. doi: 10.1016/ S0140-6736(17)32129-3

2. Garrido-Miguel M, Cavero-Redondo I, Alvarez-Bueno C, Rodriguez-Artalejo F, Moreno LA, Ruiz JR, et al. Prevalence and trends of overweight and obesity in European children from 1999 to 2016: a systematic review and meta-analysis. JAMA Pediatr 2019; 173(10): e192430. doi: 10.1001/ jamapediatrics.2019.2430

3. Nordic Council of Ministers. Nordic Nutrition Recommendations 2012: integrating nutrition and physical activity. Copenhagen: Nordic Council of Minsters; 2014.

4. Rolland-Cachera MF, Deheeger M, Akrout M, Bellisle F. Influence of macronutrients on adiposity development: a follow up study of nutrition and growth from 10 months to 8 years of age. Int J Obes Rel Metab Disord 1995; 19(8): 573-8.

5. Hornell A, Lagstrom H, Lande B, Thorsdottir I. Protein intake from 0 to 18 years of age and its relation to health: a systematic literature review for the 5 th Nordic Nutrition Recommendations. Food Nutr Res 2013; 57: 21083. doi: 10.3402/fnr.v57i0.21083

6. Pearce J, Langley-Evans SC. The types of food introduced during complementary feeding and risk of childhood obesity: a systematic review. Int J Obes (Lond) 2013; 37(4): 477-85. doi: 10.1038/ijo.2013.8

7. Ferre N, Luque V, Closa-Monasterolo R, Zaragoza-Jordana M, Gispert-Llaurado M, Grote V, et al. Association of protein intake during the second year of life with weight gain-related outcomes in childhood: a systematic review. Nutrients 2021; 13(2): 583. doi: 10.3390/nu13020583

8. Stokes A, Campbell KJ, Yu HJ, Szymlek-Gay EA, Abbott G, He QQ, et al. Protein intake from birth to 2 years and obesity outcomes in later childhood and adolescence: a systematic review of prospective cohort studies. Adv Nutr 2021; 12(5): 1863-1876. doi: 10.1093/advances/nmab034

9. Nilsson M, Stenberg M, Frid AH, Holst JJ, Bjorck IM. Glycemia and insulinemia in healthy subjects after lactose-equivalent meals of milk and other food proteins: the role of plasma amino acids and incretins. Am J Clin Nutr 2004; 80(5): 1246-53. doi: 10.1093/ajcn/80.5.1246

10. Christensen JJ, Arnesen EK, Andersen R, Eneroth H, Erkkola M, Høyer A, et al. The Nordic Nutrition Recommendations 2022 - principles and methodologies. Food Nutr Res 2020; 64: 4402. doi: 10.29219/fnr.v64.4402

11. Høyer A, Christensen JJ, Arnesen EK, Andersen R, Eneroth $\mathrm{H}$, Erkkola M, et al. The Nordic Nutrition Recommendations 2022 - prioritisation of topics for de novo systematic reviews. Food Nutr Res. 2021; 65: 7828. doi: 10.29219/fnr.v65.7828 
12. Arnesen EK, Christensen JJ, Andersen R, Eneroth H, Erkkola M, Høyer A, et al. The Nordic Nutrition Recommendations 2022 - handbook for systematic reviews. Food Nutr Res 2020; 64: 4404 doi: 10.29219/fnr.v64.4404

13. Arnesen EK, Christensen JJ, Andersen R, Eneroth H, Erkkola M, Høyer A, et al. The Nordic Nutrition Recommendations 2022 - structure and rationale of systematic reviews. Food Nutr Res 2020; 64: 4403. doi: 10.29219/fnr.v64.4403

14. Page MJ, McKenzie JE, Bossuyt PM, Boutron I, Hoffmann TC, Mulrow CD, et al. The PRISMA 2020 statement: an updated guideline for reporting systematic reviews. BMJ 2021; 372: n71. doi: 10.1136/bmj.n71

15. Page MJ, Moher D, Bossuyt PM, Boutron I, Hoffmann TC, Mulrow CD, et al. PRISMA 2020 explanation and elaboration: updated guidance and exemplars for reporting systematic reviews. BMJ 2021; 372: n160. doi: 10.1136/bmj.n160

16. Sterne JA, Savovic J, Page MJ, Elbers RG, Blencowe NS, Boutron I, et al. RoB 2: a revised tool for assessing risk of bias in randomised trials. BMJ 2019; 366: 14898. doi: 10.1136/bmj. 14898

17. Sterne JA, Hernan MA, Reeves BC, Savovic J, Berkman ND, Viswanathan M, et al. ROBINS-I: a tool for assessing risk of bias in non-randomised studies of interventions. BMJ 2016; 355: i4919. doi: 10.1136/bmj.i4919

18. Viswanathan $M$, Patnode $C D$, Berkman ND, Bass EB, Chang S, Hartling L, et al. Recommendations for assessing the risk of bias in systematic reviews of health-care interventions. J Clin Epidemiol 2018; 97: 26-34. doi: 10.1016/j. jclinepi.2017.12.004

19. Nutrition Evidence Systematic Review. Risk of Bias for Nutrition Observational Studies (RoB-NObs) tool 2019. Available from: https://nesr.usda.gov/sites/default/files/2019-07/RiskOfBiasForNutritionObservationalStudies-RoB-NObs.pdf [cited 06 February 2020].

20. AHRQ. Methods guide for effectiveness and comparative effectiveness reviews. Rockville, MD: Agency for Healthcare Research and Quality; 2014.

21. Morton SC, Murad MH, O'Connor E, Lee CS, Booth M, Vandermeer BW, et al. Quantitative synthesis - and update. 2018. In: Methods guide for effectiveness and comparative effectiveness reviews. Agency for Healthcare Research and Quality. Available from: http://www.ncbi.nlm.nih.gov/books/NBK519365 [cited 3 September 2021].

22. Deeks JJ, Higgins JPT, Altman DG. Analysing data and undertaking meta-analyses. In: Higgins JPT, Altman DG, editors. Cochrane handbook for systematic reviews of interventions, version 5.1.0. London: The Cochrane Collaboration, 2011; pp. 1-44.

23. Sterne JAC, Egger M, Moher D. Addresing reporting biases. In: Higgins JPT, Green S, editors. Cochrane handbook for systematic reviews of interventions version 5.1.0. The Cochrane Collaboration; 2011. Available from: http://handbook-5-1.cochrane.org [cited 1 February 2021].

24. Svahn JC, Axelsson IE, Raiha NC. Macronutrient and energy intakes in young children fed milk products containing different quantities and qualities of fat and protein. J Pediatr Gastroenterol Nutr 1999;29(3): 273-81. doi: 10.1097/00005176-199909000-00007

25. Krebs NF, Westcott JE, Butler N, Robinson C, Bell M, Hambidge KM. Meat as a first complementary food for breastfed infants: feasibility and impact on zinc intake and status. J Pediatr Gastroenterol Nutr 2006; 42(2): 207-14. doi: 10.1097/01. mpg.0000189346.25172.fd

26. Larnkjaer A, Hoppe C, Molgaard C, Michaelsen KF. The effects of whole milk and infant formula on growth and IGF-I in late infancy. Eur J Clin Nutr 2009; 63(8): 956-63. doi: 10.1038/ ejen.2008.80

27. Tang M, Krebs NF. High protein intake from meat as complementary food increases growth but not adiposity in breastfed infants: a randomized trial. Am J Clin Nutr 2014; 100(5): 1322-8. doi: 10.3945/ajen.114.088807

28. Tang M, Hendricks AE, Krebs NF. A meat- or dairy-based complementary diet leads to distinct growth patterns in formula-fed infants: a randomized controlled trial. Am J Clin Nutr 2018; 107(5): 734-42. doi: 10.1093/ajcn/nqy038

29. Tang M, Andersen V, Hendricks AE, Krebs NF. Different growth patterns persist at 24 months of age in formula-fed infants randomized to consume a meat- or dairy-based complementary diet from 5 to 12 months of age. J Pediatri 2019; 206: 78-82. doi: 10.1016/j.jpeds.2018.10.020

30. Scaglioni S, Agostoni C, Notaris RD, Radaelli G, Radice N, Valenti M, et al. Early macronutrient intake and overweight at five years of age. Int J Obes Relat Metab Disord 2000; 24(6): 777-81. doi: 10.1038/sj.ijo.0801225

31. Gunnarsdottir I, Thorsdottir I. Relationship between growth and feeding in infancy and body mass index at the age of 6 years. Int J Obes Relat Metab Disord 2003; 27(12): 1523-7. doi: 10.1038/sj.ijo.0802438

32. Hoppe C, Molgaard C, Thomsen BL, Juul A, Michaelsen KF. Protein intake at 9 mo of age is associated with body size but not with body fat in 10-y-old Danish children. Am J Clin Nutr 2004; 79(3): 494-501. doi: 10.1093/ajen/79.3.494

33. Skinner JD, Bounds W, Carruth BR, Morris M, Ziegler P. Predictors of children's body mass index: a longitudinal study of diet and growth in children aged 2-8 y. Int J Obes Relat Metab Disord 2004; 28(4): 476-82. doi: 10.1038/sj.ijo.0802405

34. Gunther AL, Buyken AE, Kroke A. Protein intake during the period of complementary feeding and early childhood and the association with body mass index and percentage body fat at 7 y of age. Am J Clin Nutr 2007; 85(6): 1626-33. doi: 10.1093/ ajcn/85.6.1626

35. Gunther AL, Remer T, Kroke A, Buyken AE. Early protein intake and later obesity risk: which protein sources at which time points throughout infancy and childhood are important for body mass index and body fat percentage at $7 \mathrm{y}$ of age? Am J Clin Nutr 2007; 86(6): 1765-72. doi: 10.1093/ajen/86.5.1765

36. Ohlund I, Hernell O, Hornell A, Stenlund H, Lind T. BMI at 4 years of age is associated with previous and current protein intake and with paternal BMI. Eur J Clin Nutr 2010; 64(2): 138-45. doi: 10.1038/ejen.2009.132

37. Garden FL, Marks GB, Almqvist C, Simpson JM, Webb KL. Infant and early childhood dietary predictors of overweight at age 8 years in the CAPS population. Eur J Clin Nutr 2011; 65(4): 454-62. doi: 10.1038/ejen.2011.7

38. Thorisdottir B, Gunnarsdottir I, Palsson GI, Halldorsson TI, Thorsdottir I. Animal protein intake at 12 months is associated with growth factors at the age of six. Acta Paediatr 2014; 103(5): 512-17. doi: 10.1111/apa.12576

39. Braun KV, Erler NS, Kiefte-de Jong JC, Jaddoe VW, van den Hooven EH, Franco OH, et al. Dietary intake of protein in early childhood is associated with growth trajectories between 1 and 9 years of age. J Nutr 2016; 146(11): 2361-7. doi: 10.3945/ jn. 116.237164

40. Voortman T, Braun KV, Kiefte-de Jong JC, Jaddoe VW, Franco OH, van den Hooven EH. Protein intake in early childhood and body composition at the age of 6 years: the generation R study. Int J Obes 2016; 40(6): 1018-25. doi: 10.3945/ jn. 116.237164 
41. Voortman T, van den Hooven EH, Tielemans MJ, Hofman A, Kiefte-de Jong JC, Jaddoe VW, et al. Protein intake in early childhood and cardiometabolic health at school age: the generation R study. Eur J Nutr 2016; 55(6): 2117-27. doi: 10.1007/ s00394-015-1026-7

42. Pimpin L, Jebb S, Johnson L, Wardle J, Ambrosini GL. Dietary protein intake is associated with body mass index and weight up to $5 \mathrm{y}$ of age in a prospective cohort of twins. Am $\mathrm{J}$ Clin Nutr 2016; 103(2): 389-97. doi: 10.3945/ajen.115.118612

43. Beyerlein A, Uusitalo UM, Virtanen SM, Vehik K, Yang J, Winkler C, et al. Intake of energy and protein is associated with overweight risk at age 5.5 years: results from the prospective TEDDY study. Obesity 2017; 25(8): 1435-41. doi: 10.1002/ oby. 21897

44. Durao C, Oliveira A, Santos AC, Severo M, Guerra A, Barros $\mathrm{H}$, et al. Protein intake and dietary glycemic load of 4-year-olds and association with adiposity and serum insulin at 7 years of age: sex-nutrient and nutrient-nutrient interactions. Int $\mathrm{J}$ Obes 2017; 41(4): 533-41. doi: 10.1038/ijo.2016.240

45. Pimpin L, Jebb SA, Johnson L, Llewellyn C, Ambrosini GL. Sources and pattern of protein intake and risk of overweight or obesity in young UK twins. Br J Nutr 2018; 120(7): 820-9. doi: 10.1017/S0007114518002052

46. Morgen CS, Angquist L, Baker JL, Andersen AN, Sorensen TIA, Michaelsen KF. Breastfeeding and complementary feeding in relation to body mass index and overweight at ages 7 and $11 \mathrm{y}$ : a path analysis within the Danish National Birth Cohort. Am J Clin Nutr 2018; 107(3): 313-22. doi: 10.1093/ ajcn/nqx058

47. Smith-Brown P, Morrison M, Krause L, Newby R, Davies PS. Growth and protein-rich food intake in infancy is associated with fat-free mass index at 2-3 years of age. J Paediatr Child Health 2018; 54(7): 770-5. doi: 10.1111/jpc.13863

48. Jen V, Braun KVE, Karagounis LG, Nguyen AN, Jaddoe VWV, Schoufour JD, et al. Longitudinal association of dietary protein intake in infancy and adiposity throughout childhood. Clin Nutr 2019; 38(3): 1296-302. doi: 10.1016/j. clnu.2018.05.013

49. Switkowski KM, Jacques PF, Must A, Fleisch A, Oken E. Associations of protein intake in early childhood with body composition, height, and insulin-like growth factor I in mid-childhood and early adolescence. Am J Clin Nutr 2019; 109(4): 1154-63. doi: 10.1093/ajen/nqy354

50. Gunther AL, Buyken AE, Kroke A. The influence of habitual protein intake in early childhood on BMI and age at adiposity rebound: results from the DONALD study. Int J Obes 2006; 30(7): 1072-9. doi: 10.1038/sj.ijo.0803288

51. Rolland-Cachera MF, Deheeger M, Maillot M, Bellisle F. Early adiposity rebound: causes and consequences for obesity in children and adults. Int J Obes (Lond) 2006; 30 Suppl 4: S11-17. doi: 10.1038/sj.ijo.0803514

52. Fleddermann M, Demmelmair H, Grote V, Nikolic T, Trisic B, Koletzko B. Infant formula composition affects energetic efficiency for growth: the BeMIM study, a randomized controlled trial. Clin Nutr 2014; 33(4): 588-95. doi: 10.1016/j. clnu.2013.12.007

53. Koletzko B, von Kries R, Closa R, Escribano J, Scaglioni S, Giovannini $\mathrm{M}$, et al. Lower protein in infant formula is associated with lower weight up to age $2 \mathrm{y}$ : a randomized clinical trial. Am J Clin Nutr 2009; 89(6): 1836-45. doi: 10.3945/ ajen.2008.27091

54. Wall CR, Hill RJ, Lovell AL, Matsuyama M, Milne T, Grant CC, et al. A multicenter, double-blind, randomized, placebo-controlled trial to evaluate the effect of consuming growing up milk 'lite' on body composition in children aged 12-23 mo. Am J Clin Nutr 2019; 109(3): 576-85. doi: 10.1093/ ajcn/nqy302

55. Patro-Golab B, Zalewski BM, Kouwenhoven SM, Karas J, Koletzko B, Bernard van Goudoever J, et al. Protein concentration in milk formula, growth, and later risk of obesity: a systematic review. J Nutr 2016; 146(3): 551-64. doi: 10.3945/ jn. 115.223651

56. Abrams SA, Hawthorne KM, Pammi M. A systematic review of controlled trials of lower-protein or energy-containing infant formulas for use by healthy full-term infants. Adv Nutr 2015; 6(2): 178-88. doi: 10.3945/an.114.006379

57. English LK, Obbagy JE, Wong YP, Butte NF, Dewey KG, Fox MK, et al. Types and amounts of complementary foods and beverages consumed and growth, size, and body composition: a systematic review. Am J Clin Nutr 2019; 109(Suppl_7): 956S77S. doi: 10.1093/ajen/nqy281

58. Luque V, Closa-Monasterolo R, Escribano J, Ferre N. Early programming by protein intake: the effect of protein on adiposity development and the growth and functionality of vital organs. Nutr Metab Insights 2015; 8(Suppl 1): 49-56. doi: 10.4137/ NMI.S29525

59. Lu J, Gu Y, Liu H, Wang L, Li W, Li W, et al. Daily branchedchain amino acid intake and risks of obesity and insulin resistance in children: a cross-sectional study. Obesity (Silver Spring) 2020; 28(7): 1310-16. doi: 10.1002/oby.22834

60. Dorosty AR, Emmett PM, Cowin S, Reilly JJ. Factors associated with early adiposity rebound. ALSPAC study team. Pediatrics 2000; 105(5): 1115-18. doi: 10.1542/ peds.105.5.1115

61. NCD Risk Factor Collaboration. Heterogeneous contributions of change in population distribution of body mass index to change in obesity and underweight. Elife 2021; 10: e60060. doi: 10.7554/eLife. 60060

62. Druet C, Stettler N, Sharp S, Simmons RK, Cooper C, Smith GD, et al. Prediction of childhood obesity by infancy weight gain: an individual-level meta-analysis. Paediatr Perinat Epidemiol 2012; 26(1): 19-26. doi: 10.1111/j.1365-3016.2011.01213.x

63. Zheng M, Lamb KE, Grimes C, Laws R, Bolton K, Ong KK, et al. Rapid weight gain during infancy and subsequent adiposity: a systematic review and meta-analysis of evidence. Obes Rev 2018; 19(3): 321-32. doi: 10.1111/obr.12632

64. Simmonds M, Llewellyn A, Owen CG, Woolacott N. Predicting adult obesity from childhood obesity: a systematic review and meta-analysis. Obes Rev 2016; 17(2): 95-107. doi: 10.1111/ obr.12334

65. Bjerregaard LG, Adelborg K, Baker JL. Change in body mass index from childhood onwards and risk of adult cardiovascular disease. Trends Cardiovasc Med 2020; 30(1): 39-45. doi: 10.1016/j.tcm.2019.01.011

66. Meyer JF, Larsen SB, Blond K, Damsgaard CT, Bjerregaard LG, Baker JL. Associations between body mass index and height during childhood and adolescence and the risk of coronary heart disease in adulthood: a systematic review and meta-analysis. Obes Rev 2021; 22(9): e13276. doi: 10.1111/obr.13276

67. Park MH, Falconer C, Viner RM, Kinra S. The impact of childhood obesity on morbidity and mortality in adulthood: a systematic review. Obes Rev 2012; 13(11): 985-1000. doi: 10.1111/j.1467-789X.2012.01015.x

68. Flegal KM, Ogden CL. Childhood obesity: are we all speaking the same language? Adv Nutr 2011; 2(2): 159S-66S. doi: 10.3945/an.111.000307 
69. Lobstein T, Baur L, Uauy R, IASO International Obesity Task Force. Obesity in children and young people: a crisis in public health. Obes Rev 2004; 5 Suppl 1: 4-104. doi: 10.1111/j.1467-789X.2004.00133.x

70. Martin-Calvo N, Moreno-Galarraga L, Martinez-Gonzalez MA. Association between body mass index, waist-to-height ratio and adiposity in children: a systematic review and meta-analysis. Nutrients 2016; 8(8): 512. doi: 10.3390/nu8080512

71. Simmonds M, Llewellyn A, Owen CG, Woolacott N. Simple tests for the diagnosis of childhood obesity: a systematic review and meta-analysis. Obes Rev 2016; 17(12): 1301-15. doi: 10.1111/obr.12462

\section{*Erik Kristoffer Arnesen}

Division of Clinical Nutrition

University of Oslo

Box 1046 Blindern

0317 Oslo, Norway

Email: e.k.arnesen@medisin.uio.no 